\title{
KSČ A ŘíZENÍ CENTRÁLNĚ PLÁNOVANÉ EKONOMIKY: MEZI MOCENSKÝM IMPERATIVEM A EKONOMICKOU RACIONALITOU
}

\section{VLADIMÍR HANDL}

FAKULTA SOCIÁLNÍCH VĚD UNIVERZITY KARLOVY

\begin{abstract}
The Communist Party of Czechoslovakia and Central Planning: Between the Imperative of Power and Economic Rationality

The article deals with the Communist Party of Czechoslovakia's role in the country's centrally planned economy during the late 1980s. It looks into the mechanisms of implementation of the party's constitutional "leading role" in steering the economy. Furthermore, it examines how the party's role was perceived among members of the nomenclature in the party's Central Committee as well as its regional organizations and by the management of economic enterprises. For these purposes, the text analyzes archival documents of the Politburo and other Central Committee institutions. In addition, semi-structured interviews with former party members on the regional level and with former economic players on the level of enterprises were conducted. One of the findings is that the party's role in steering the economy was divisive towards both the society and the party itself. The paper also demonstrates that the Central Committee was divided into ideological hardliners and members dealing with the real economy. The article concludes by identifying four real roles the party played in steering the economy, and points to the considerable level of voluntarism in the individual players' actions.
\end{abstract}

Keywords: Communist Party of Czechoslovakia; central planning; enterprises; trade unions; perestroika; oral history

DOI: $10.14712 / 23363231.2019 .2$

\footnotetext{
Vznik tohoto článku byl podpořen Grantovou agenturou ČR (projekt č. 15-09404S).

JUDr. Vladimír Handl, CSc., působí jako výzkumný pracovník Institutu mezinárodních studií FSV UK. Korespondenční adresa: Institut mezinárodních studií, Fakulta sociálních věd UK, U Kříže 8, 15800 Praha 5.E-mail: vladimir.handl@fsv.cuni.cz.

Autor děkuje Adéle Bráchové a Kláře Bundové, studentkám Institutu mezinárodních studií FSV UK, za vyhledání a pořízení fotokopií archivních dokumentů, jakož i Antonínu Handlovi za pomoc se zpracováním pořízených rozhovorů. Dík patři dále dvěma anonymním recenzentům, kteří cennými radami přispěli k dopracování textu do předkládané závěrečné podoby. Poděkování si zaslouží i redakce časopisu AUC Studia Territorialia za nadstandardní ediční péči.
} 


\section{Úvod}

V literatuře o centrálně plánované ekonomice ČSSR platí teze, že československý normalizační režim zůstal v ekonomice až do konce své existence více méně „puristický“. Bez větších změn se držel modelu centrálně plánovaného hospodárství, jak byl vytvořen v padesátých letech 20. století, nebot českoslovenští komunisté k žádným větším inovacím nesáhli. ${ }^{1}$ Předkládaný text toto tvrzení nerozporuje, snaží se ale osvětlit praxi uplatňování „vedoucí úlohy“ Komunistické strany Československa (KSČ) při řízení ekonomiky.

Literatura o centrálně plánované ekonomice se o teorii a praxi uplatňování vedoucí úlohy strany zmiňuje jen okrajově. Uvádí se tak, že tradiční model ekonomiky socialismu vycházel ze sovětské zkušenosti centrálně plánované ekonomiky období rychlé industrializace a doby světové hospodářské krize třicátých let. Byl založen na striktní centralizaci (všechna podstatná rozhodnutí se přijímala na centrální úrovni), při plánování a řízení ekonomiky dominovaly vertikální vazby; plán měl převážně imperativní charakter (na rozdíl od tzv. indikativního plánování) a jeho politickým předpokladem byla existence autoritářského politického systému či prímo diktatury. ${ }^{2}$ János Kornai definoval tradiční model centrálně plánované ekonomiky v zemích východního bloku jako koherentní systém, v němž fungovaly kauzální vazby, kdy každý jednotlivý prvek (úroveň) určoval prvek následující. Základem systému byla nedělitelná moc marxisticko-leninské strany a dominance její ideologie. Následovala dominantní pozice státu a kvazi-státního vlastnictví. Třetí prvek představovala převažující byrokratická koordinace a tvorba plánu, důraz na kvantitativní ukazatele, paternalismus, měkká rozpočtová omezení a slabá odezva na vývoj cen. Poslední rovinu představoval nucený růst, nedostatková ekonomika a nedostatek pracovních sil. ${ }^{3}$

Další autoři uváděli, že systém, na jehož základě státní socialismus sovětského typu fungoval, měl podle stranické ideologie zajištovat legitimitu a efektivitu vládnutí pro období mezi převzetím moci a vytvořením nové společnosti. ${ }^{4}$ Mechanismus přežití přitom předpokládal, že systém - a v jeho čele strana - bude plnit funkci sebepotvrzení (self-justification), sebedefinice cílů (self-targeting)

1 Lubomír Kopeček, Éra nevinnosti. Česká politika 1989-1997 (Brno: Barrister \& Principal, 2010), $10-22$.

2 Michael Ellmann, Socialist Planning (Cambridge: Cambridge University Press, 2014), 22-23.

3 Jánosz Kornai, The Socialist System (Oxford: Oxford University Press, 1992), cit. podle Ellmann, Socialist Planning, 23.

4 Pawel H. Dembinski, The Logic of The Planned Economy. The Seeds of the Collapse (Oxford: Clarendon Press, 1991). 
a sebeorganizace. Pro sebeidentifikaci bylo nezbytné opírat interpretaci činnosti strany obecně o marxisticko-leninský kánon, konkrétně o ideový „referenční rámec“, který vedení strany mohlo pojímat podle vývoje konstelace bud' velmi striktně, nebo postupně i pružněji. Zejména v osmdesátých letech šlo o vývoj systému pod rostoucím tlakem na provedení reforem jako „zásadní institucionální změny, která by nahradila tradiční model socialistického hospodářství alternativním modelem, jenž by kombinoval centralizované státní rozhodování s tržními mechanismy“. 5 Úspěšná reforma ovšem předpokládala příznivé politické podmínky, jaké reformnímu procesu v té době poskytoval Michail Gorbačov ve Svazu sovětských socialistických republik (SSSR) nebo dříve československý vývoj před rokem 1968.6

Následující text vznikl v rámci projektu „Reálné fungování centrálně plánované ekonomiky v Československu (období pozdního socialismu, 70.-80. léta)“, který se nesoustředil na makroenomickou úroveň, nýbrž na úroveň podnikovou. Projekt tak řešil otázky, jak v daných normativních, institucionálních a ekonomických podmínkách probíhaly ekonomické aktivity právě na té nejnižší, tedy podnikové úrovni. Pokud jde o sektor ekonomiky, zabýval se projekt především oblastí strojírenství, dopravy a palivo-energetickým komplexem.

Otázky, které si tento př́íspěvek klade, se týkají podmínek politických. Konkrétně se zaměřují na to, jakým způsobem pojímala a interpretovala při řízení centrálně plánované ekonomiky svoji „vedoucí úlohu“ Komunistická strana Československa. Jaké byly mechanismy naplňování vedoucí úlohy strany, jaké uplatňovala postupy a jaké používala instrumenty? A jak její roli vnímali odpovědní pracovníci v rámci stranického aparátu a vedoucí hospodářští pracovníci v podnicích?

Odborná literatura otázky postupu strany osvětluje jen omezeně. Mechanismus řízení popsal především Karel Kaplan ve své práci o fungování ústředních stranických orgánů v padesátých až šedesátých letech. ${ }^{7}$ Poukazuje na to, že zejména předsednictvo Ústředního výboru KSČ (dále PÚV) rozhodovalo o všem, a to především z politického hlediska, přičemž za svá rozhodnutí nepřijímalo odpovědnost; ta ležela na státních orgánech, především vládě. Kaplan rovněž dokládá, že PÚV často rozhodovalo, aniž by znalo pravý stav věcí, protože $z$ důvodů vnitřní mocenské konkurence zde neprobíhala skutečná debata.

5 Ellmann, Socialist Planning, 53.

6 Ibid., 78.

7 Karel Kaplan, Anatomie einer regierenden kommunistischen Partei, II. (Köln: Bundesinstitut für ostwissenschaftliche und internationale Studien, 1983). 
Kaplanův závěr je, že PÚV jako klíčový orgán nebylo schopno inovace a reforem, protože jakékoli změny mohly potenciálně ohrozit jeho mocenskou pozici.

Pokud jde o fungování podnikové sféry a způsob naplňování vedoucí úlohy KSČ v sedmdesátých až osmdesátých letech, je nutné za klíčové považovat práce Lubomíra Mlčocha, zpracované ve výzkumných institucích komunistické ČSSR ještě před listopadem 1989. Jeho „deskriptivní studie“ obsahují nejpodrobnější analýzu fungování hierarchické struktury systému a chování podniků v ní. Mlčoch mluví o „uzavřeném hierarchickém plánovacím systému“ a „hierarchické koaliční struktuře“, „neodstranitelné převrácené řídící pyramidě“, jež neumožňovaly objektivní hodnocení hospodářství a následná opatření. Místo plánování tak podle něho probíhala „hra o plán“. Neparametrický systém (tj. odtržený od reálných, ekonomicky tvořených cen) omezoval funkčnost horizontálních vazeb hospodářských subjektů a podniky je musely kompenzovat budováním vertikálních vazeb na nadpodnikové struktury. Rídily se „sacím reflexem“ a chovaly se jako „chobotnice“ - ve snaze získat co nejvyšší podíl na společenských zdrojích se napojovaly na plánovací kanály. ${ }^{8}$

Mlčoch přitom vycházel z toho, že na podnikové úrovni fungovaly tzv. „kontrolní skupiny“, jež zahrnovaly vedoucí hospodářské pracovníky, podnikové stranické a odborové vedení. Právě ony byly okolnostmi vedeny $\mathrm{k}$ tomu, aby do koalice zahrnovaly externí aktéry z nadpodnikových struktur, ${ }^{9}$ které by podniku umožňovaly úspěšně vstupovat do „hry o plán“. Takto vytvořený neparametrický systém prezentoval Mlčoch jako nereformovatelný, protože ekonomika byla založena na silových a mocenských působeních. Z hlediska práva disponovat společenským majetkem bylo zespolečenštění pouze formální a faktickými vlastníky byl centrální stát, vedení podniků a stranické instituce, nikoli řadoví zaměstnanci. ${ }^{10}$

Na základě Kaplanovy a Mlčochovy interpretace fungování stranických orgánů, státních a podnikových institucí si následující analýza klade otázky, zda se změnil mechanismus řízení orgánů ÚV v období osmdesátých let. Zkoumá zejména to, nakolik kompetentně a jak informovaně probíhala jednání a rozhodování a na jaké otázky se soustředila. Jak svou roli a její naplňování hodnotily samotné instituce ÚV KSČ? Nakolik byly instituce ústředního výboru

\footnotetext{
${ }^{8}$ Lubomír Mlčoch, Chováni československépodnikovésféry (Praha: Ekonomický ústav ČSAV, 1990), $18,34,233-235$, passim.

9 Dušan Tříska hovoří v takovém př́ípadě o „rídících koalicích“. Viz Dušan Tř́íska, „Ekonomické centrum, peníze a monopoly“, in Přestavba hospodářského mechanismu, ekonomické klima a institucionální uspořádání ekonomiky, ed. Antonín Kotulan et al. (Praha: Ekonomický ústav ČSAV, 1990), 10.

${ }^{10}$ Mlčoch, Chování československé podnikové sféry, 77-79, 210, 220.
} 
vnitřně diferencované, zejména $\mathrm{v}$ otázce změn v řízení ekonomiky a potřeby reforem? Jak se projevovalo rozdělení mezi modernizátory a zastánci statu quo a dogmatiky, popisované hojně v literatuře o období po roce 1968? Proč se před rokem 1989 ve fungování ekonomiky nepodařilo prosadit žádné zásadní změny? Druhá rovina otázek se věnuje tomu, jak KSČ naplňovala svoji vedoucí úlohu na podnikové úrovni: jaké funkce na spodních úrovních rrízení plnila jednak z pohledu stranického aparátu, jednak z pohledu hospodářských pracovníků na podnicích?

Z hlediska použitých metod se práce soustředí na rozbor vybraných dokumentů $\mathrm{z}$ archivu PÚV, které charakterizují postup ústředních orgánů ÚV KSČ v průběhu osmdesátých let. Snaží se přitom mj. porovnat přístup politických institucí ÚV KSČ (PÚV a Ústřední kontrolní a revizní komise) a ekonomických oddělení ÚV KSČ. ${ }^{11}$ Výsledný obraz je konfrontován s tím, jak naplňování „vedoucí úlohy“ KSČ vnímali straničtí aktéři na okresní a krajské úrovni na jedné straně a jak ji hodnotili odpovědní hospodářští pracovníci a pracovníci státních institucí (Státní plánovací komise) na straně druhé. ${ }^{12}$ Práce pro tyto účely používá polostrukturované rozhovory s vybranými aktéry. Výběr respondentů byl dán tím, nakolik byli jednotliví respondenti relevantní pro jednotlivé roviny výzkumu - ústřední orgány, střední rovinu stranického řízení (kraje a okresy) a podniky. Výběr byl přirozeně značně omezen tím, zda byly oslovené osoby schopny a ochotny o daných tématech otevřeně hovořit. Text $v$ současné podobě uvádí shrnutí výpovědí způsobem, který je inspirován pracemi v oblasti orální historie. Polostrukturované rozhovory, i když nemohou být vzhledem k nízkému počtu respondentů reprezentativní, představují důležitý zdroj informací o tom, jak na stranu nahlíželi její tehdejší členové - at už straničtí funkcionáři, nebo hospodářští aktéři. Vycházíme přitom z premisy, že „[o]rální historie by neměla být vnímána jako opak archivních písemných zdrojů, ale představovat [oba zdroje - pozn. aut.] jako dvě strany téže mince. Podobně by historie měla zahrnovat jak fakta o událostech [...], tak osobní zkušenosti jednotlivců, kteří tyto události prožívali, kteří na ně reagovali a jejichž chování pomáhalo formovat tempo a směr daných událostí“.13

11 Veškeré dokumenty pocházejí z Národního archivu, z fondů Předsednictva ÚV KSČ z let 1980-1989 (1261/0/8 a 1261/0/9). Případné drobné inkonzistence v zápisu pramenů jsou dány tím, že uvedené fondy teprve procházejí inventarizací.

12 Záznamy a přepisy všech rozhovorů jsou založeny v dokumentaci projektu GAČR č. 15-09404S.

${ }^{13}$ Miroslav Vaněk, „Those Who Prevailed and Those Who Were Replaced: Interviewing on Both Sides of a Conflict", in The Oxford Handbook of Oral History, ed. Donald A. Ritchie (Oxford: Oxford University Press, 2010), 37. 
Přínos práce spatřujeme $\mathrm{v}$ analýze dosud málo probádaného tématu, zahrnutí archivních dokumentů PÚV a konfrontaci této roviny analýzy s pohledy dobových aktérů jak na straně řídící složky (KSČ, uplatňující svou „vedoucí úlohu“), tak mezi hospodářskými aktéry na úrovni podniků. ${ }^{14}$

První část studie na základě dostupné literatury stručně přibližuje vývoj př́stupu strany k řízení ekonomiky po roce 1968. Druhá část rekonstruuje prostřednictvím vybraných dokumentů předsednictva ÚV KSČ způsob, jakým centrální orgány ÚV KSČ uplatňovaly roli strany při řízení ekonomiky. Třetí část je založena na vyhodnocení interview se stranickými aktéry na regionální úrovni a s vedoucími hospodářskými pracovníky na úrovni podniků. Závěr stručně shrnuje hlavní poznatky, odpovídá na otázky a snaží se typizovat funkce, které se strana snažila naplňovat.

\section{KSČ a vývoj řízení centrálně plánované ekonomiky po roce 1968}

Po potlačení Pražského jara 1968 se strana vrátila k centralistickému pojetí politiky a $\mathrm{k}$ marxisticko-leninské ideologii, ačkoli to neznamenalo plný návrat $\mathrm{k}$ centrálně-administrativnímu systému doby stalinismu. ${ }^{15}$ Vzhledem k již nasbíraným zkušenostem a započatým reformám se změny staly „historickým a gnozeologickým anachronismem“ - centrum opět plně ovládlo hospodářství a nedávno získané větší pravomoci podniků byly znovu oslabeny. ${ }^{16}$

S nástupem Gustáva Husáka do čela KSČ byla obnovena vedoucí úloha strany v ekonomice a dalších oblastech společenského života. ${ }^{17} \mathrm{~V}$ prosinci 1970 byl přijat dokument „Poučení z krizového vývoje ve straně a společnosti

${ }^{14}$ Po odevzdání rukopisu do tisku byly v časopise Soudobé dějiny publikovány tři studie, které se týkají tématu tohoto článku a které by čtenár neměl opominout. Viz Vítězslav Sommer, „Manažerská odysea. Teorie řízení v Československu v padesátých až osmdesátých letech 20. století“, Soudobé dějiny 24, č. 3 (2017): 285-310; Tomáš Vilímek, „,Kdo řídí - kontroluje“. Podnikový management a úskalí ,socialistické kontroly' v československých podnicích v osmdesátých letech 20. století“, Soudobé dějiny 24, č. 3 (2017): 361-388; Václav Rameš, „(Post)socialističtí ekonomové jako objekt historického zkoumání. Současný stav a perspektivy“, Soudobé dějiny 24, č. 3 (2017): 389-402. Závěry těchto prací bude autor reflektovat ve svém dalším výzkumu.

15 Jiří Kosta, Abriß der sozialökonomischen Entwicklung der Tschechoslowakei 1945-1977 (Frankfurt a. M.: Suhrkamp, 1978), 171-173.

${ }^{16}$ Lenka Kalinová, Konec nadějím a nová očekávání. K dějinám české společnosti 1969-1993 (Praha: Academia, 2012), 81.

17 Václav Průcha a kol., Hospodářské a sociálni dějiny Československa 1918-1992, 2. díl (Brno: Doplněk, 2009), 659-660. 
po XIII. sjezdu KSČ“ a rovněž „Rezoluce o aktuálních otázkách jednoty strany“. ${ }^{18}$ Poučení $\mathrm{z}$ krizového vývoje se stalo pro „zdravé jádro“ ve straně trvalým normativním dokumentem, podle nějž se posuzoval jak vývoj ve společnosti, tak zejména vývoj ve straně a její politice. ${ }^{19}$ Hodnocení chyb vedoucích k roku 1968 se $\mathrm{v}$ „Poučení“ omezilo na subjektivní nedostatky a působení „protisocialistických“ sil; nepřipouštěly se žádné nedostatky systému. Lubomír Štrougal přitom vzpomínal, že ,jsme v ÚV strany již v roce 1957 dospěli k závěru, že od daného administrativního systému je třeba programově ustoupit a postupně uplatňovat prvky ekonomického řízení. Podnik [...] je v tomto systému základní ekonomický subjekt, který se v konkurenčním prostředí snaží uplatnit na domácím či zahraničním trhu. Tato rozhodnutí zůstala bohužel nenaplněna.“20

„Poučení“ na rozdíl od zastánců ekonomické reformy chybu strany spatřovalo hlavně v nedostatečné ideové práci, v jejím „ideologickém odzbrojení“ a v nedostatečné výchově členů i ostatních pracujících, podceněno bylo dle něj „nebezpečí pronikání pravicového oportunismu a revisionismu [...], v ideologické práci se projevovala neprí́pustná defenzívnost a shovívavost“". ${ }^{21} \mathrm{~V}$ souladu s tím se KSČ měla soustředit na ideovou práci (ve straně a společnosti) a na boj proti oportunismu a revisionismu a za jednotu strany. ${ }^{22}$ Otázka systémových změn se pro většinu vedení KSČ, vyneseného do vrcholných pozic po potlačení reformního procesu Pražského jara 1968, stala tabu. Z pohledu tohoto „zdravého jádra“ byla každá zmínka o systémových změnách ohrožením, návratem k ideové herezi šedesátých let, a byla tedy posuzována se skepsí, obavou a v jakékoli výraznější podobě byla odmítána.

Pojetí roku 1968 jako boje proti „pravičákům“ ve vedení strany muselo nutně vyústit do rozsáhlých čistek ve stranickém a státním aparátu i v podnicích. V letech 1969 až 1975 bylo vyloučeno nebo vyškrtnuto z KSČ 489648 členů a kandidátů strany, z úřadů federální vlády muselo odejít 1041 (tj. 9,9\%) osob, z úřadů české vlády 683 (tj. 10,3\%) osob; podobně byla postižena hospodářská

18 Poučení z krizového vývoje ve straně a společnosti po XIII. sjezdu KSČ. Rezoluce o aktuálních otázkách jednoty strany, schválená na plenárním zasedání ÚV KSČ v prosinci 1970. Vydalo oddělení propagandy a agitace ÚV KSČ (Praha: Rudé Právo, 1971).

19 Jako př́íklad uved'me konferenci, která se konala v době nástupu sovětské přestavby v roce 1985. Viz Stále platné poučení - sborník materiáli z Celostátní védecko-praktické konference k 15. výroči Poučeníz krizového vývoje ve straně a společnosti po XIII. sjezdu KSČ, konanév Praze 9.-10. 12. 1985 (Praha: Svoboda, 1986).

${ }^{20}$ Lubomír Štrougal, Paméti a úvahy (Praha: Epocha, 2009), 250.

${ }^{21}$ Poučení z krizového vývoje, 7-8.

22 Rezoluce o aktuálních otázkách jednoty strany, in Poučení z krizového vývoje, 46-47. 
sféra. ${ }^{23}$ Strana celkově upevnila svou úlohu při řízení hospodářství a soustředila se na posilování disciplíny. ${ }^{24}$ XIV. sjezd roku 1971 pak znamenal ukončení hospodářského experimentu, obnovení základní struktury centrálně plánované ekonomiky, represivní potlačení politických variant vývoje a snahu nastolit a udržet sociální klid. ${ }^{25} \mathrm{Na}$ dlouho se stala jedním ze základních znaků systému nekompetentnost, kdy na místa uvolněná zaměstnanci propuštěnými z politických důvodů nastupovali lidé, u nichž se vyžadovala v podstatě jediná profesionální kompetence - vynucovaná loajalita. ${ }^{26}$ Data z poloviny roku 1971 ukazují, že předepsané vzdělání mělo ve federálních úřadech $64,3 \%$ nomenklaturních kádrů (v roce 1969 to bylo ještě 71,2 \%), v úřadech vlády ČSR 64,9 \% (oproti $82,9 \%$ v roce 1969 ) a vlády SSR $80,6 \%$ (v roce 1969 to bylo $83,7 \%$ ). ${ }^{27}$

Vždy znovu se potvrzovala převaha politiky a ideologie (a tedy zájem o stabilitu mocenského monopolu KSČ) nad zájmem o ekonomickou modernizaci a prosperitu. Ekonomický vývoj sice vedl k diskusi o reformě hospodářského systému, poprvé např. v reakci na energetickou krizi roku 1979. Federální vláda v této situaci, podle jejího tehdejšího předsedy Štrougala, vysvětlovala potřebu reformy tím, že skutečným problémem je ohromná energetická náročnost československé ekonomiky a nezájem podniků o úspory, a požadovala uplatnění podnikové a individuální zainteresovanosti a posílení ekonomické samostatnosti podniků. Nicméně, ,jako už několikrát, se většina ve vedení strany rozhodla, že nepotřebujeme reformy, ale více disciplíny. [...] [P]ostupovalo se ,osvědčeným způsobem': příčiny nejsou v systému, ale v kontrole lidí. Budeme tedy ještě více kontrolovat, psát hlášení a organizovat závazky k překonání nedostatků. [...] [H]lavním stimulem pracovní výkonnosti má být oddanost zemi, podniku a straně““ ${ }^{28}$ Husák podle Štrougala věděl, „na které straně je pravda“, ale nebyl v této době prŕiliš nakloněn tomu ekonomické problémy řešit. „Bohužel situace pro konzervativní skupinu ve vedení byla výhodná. Stejný názor, že měnit systém je riziko, zastávali i v Moskvě. [...] [̌̌ ]ada funkcionářů shora dolů se hlavně zabývala opozičními skupinami a to jen z jednoho zorného úhlu - jak opozici represivně potlačit.“29 Potřeba přímé kontroly byla ve straně přítomná obecně:

23 Vladimíra Hradecká a František Koudelka, Kádrová politika a nomenklatura KSČ 1969-1974 (Praha: Ústav pro soudobé dějiny AV ČR, 1998), 43 a 63.

${ }^{24}$ Průcha a kol., Hospodářské a sociální dějiny Československa, 2. díl, 660.

25 Jiří Vykoukal, Miroslav Tejchman a Bohuslav Litera, Východ. Vznik, vývoj a rozpad sovětského bloku 1944-1989 (Praha: Libri, 2004), 578.

${ }^{26}$ Ibid., 580.

${ }^{27}$ Hradecká a Koudelka, Kádrová politika a nomenklatura KSČ, 100.

28 Štrougal, Pamèti a úvahy, 252.

${ }^{29}$ Ibid., 253-254. 
projevovala se mj. v neustálém rozšiřování tzv. vnější nomenklatury (tj. funkcí ve státní správě a společnosti obecně, mimo vnitřní kádrový řád samotné KSČ). V roce 1974 stranické orgány různých stupňủ schvalovaly obsazení 535098 pozic vně KSČ, v roce 1987 to bylo už 717395 pozic. ${ }^{30}$ Ruku v ruce s kontrolou kádrů šla prostřednictvím nomenklaturního řádu i systematická práce při rozšiřování členské základny KSČ.

V logice tohoto přístupu nepřekvapuje, že záběr „Souboru opatření ke zdokonalení plánovitého řízení národního hospodářství po roce 1980 “ byl příliš omezený: „mnohaletá antireformní, protirevizionistická kampaň vytvořila nepřekročitelné ideologické bariéry, které jakýkoli projekt ,zdokonalování nemůže překročit“. ${ }^{31}$ To se ostatně týkalo i rozporného vztahu k takovým inovačním projektům, jako byl Agrokombinát Slušovice: na jedné straně byly Slušovice vnímány jako model a př́klad a hospodářsky orientovanými představiteli, jako byl Štrougal, byly takto prezentovány. Na straně druhé stranické orgány zjevně přesně nevěděly, jak s tímto hospodářsky velmi úspěšným a čistě ekonomicky orientovaným fenoménem nakládat, a měly z jeho přitažlivosti obavu. Rudolf Hegenbart uvádí, že jako tajemník okresního výboru KSČ (dále OV KSČ) ve Zlíně dostal neoficiální zadání „pokusit se omezit Slušovice, odstranit [jeho předsedu Františka - pozn. aut.] Čubu a zamezit kontrarevolučním tendencím slušovického systému“. Husák měl údajně „zájem[,] aby byla jejich praxe zastavena a zlikvidována“. Za odměnu měl Hegenbart přislíbeny vysoké funkce. Navíc měl sledovat vztahy mezi Slušovicemi a předsedou vlády Štrougalem. Hegenbart poté, co se s Čubou a Slušovicemi seznámil, naopak prosadil Čubu do předsednictva OV KSČ ve Zlíně. ${ }^{32}$ Př́pad potvrzuje rozštěpení strany, ale také jistou, byt omezenou možnost zastávat $\mathrm{v}$ rámci svých kompetencí vlastní pozici.

Poněkud jiná byla situace v druhé polovině osmdesátých let. Neuspokojivý průběh prvních let osmé pětiletky obnovil tlak na hledání reforem; navíc v SSSR probíhala plným tempem přestavba a to vytvářelo na vedení KSČ nepřímý tlak. Husák, jsa v té době již za zenitem svého postavení ve straně a nacházeje se pod tlakem konzervativní skupiny, zjevně chtěl př́iklonem k ekonomické přestavbě (používal dokonce zakázané slovo „reforma“) zajistit své postavení v nové politické konstelaci. V létě 1987 pronesl některé ze svých „nejradikálnějších

${ }^{30}$ Hradecká a Koudelka, Kádrová politika a nomenklatura KSČ, 98.

31 Zdislav Šulc, Stručné dějiny ekonomických reforem v Československu (České republice) 1945-1995 (Brno: Doplněk, 1998), 59.

32 „Rudolf Hegenbart“, in Vitězové? Poražení? Životopisná interview, ed. Miroslav Vaněk a Pavel Urbášek, 2. díl (Praha: Prostor, 2005), 117-118. 
přestavbových projevư “.33 Jeho aktivismus přitom už počátkem roku vedl ke konkrétnímu výsledku. Pod jeho tlakem byly uspíseny práce na „Zásadách přebudování hospodářského mechanismu ČSSR“. Ty byly nakonec zveřejněny ještě 9. ledna 1987. ${ }^{34}$ Avizován byl i zákon o státním podniku. Husákovým záměrem bylo učinit tento krok ještě před klíčovým lednovým zasedáním pléna Ústředního výboru Komunistické strany Sovětského svazu (ÚV KSSS), které s konečnou platností potvrdilo gorbačovský kurs na přestavbu. Přijetí „Zásad“ mělo ukázat, že KSČ pouze nereaguje na sovětské iniciativy. Následovaly „Směrnice k zabezpečení komplexní přestavby hospodářského mechanismu“.35 Nový zákon o státním podniku byl přijat v roce 1988 a byl radikálnější než návrh z období reformních šedesátých let; předpokládal např. volbu ředitele prostřednictvím nově zaváděných shromáždění. ${ }^{36}$ Zároveň byly zrušeny výrobně hospodářské jednotky (dále $\mathrm{VHJ}$ ), ${ }^{37}$ jež byly nahrazeny novými státními podniky $\mathrm{s}$ větší hospodářskou samostatností; systém se z třístupňového transformoval na dvoustupňový - stát/ministerstva a státní podniky.

Analýzy tohoto období ukazují, že vedení KSČ bylo o vážnosti situace informováno: komise ÚV KSČ předkládaly koncem osmdesátých let kritické analýzy hospodářské a sociální politiky; vedení je bralo na vědomí, „ale v praxi nebylo schopné ani ochotné se $\mathrm{k}$ nim kvalifikovaně vyslovit, a tím méně je řešit“.38 Politické podmínky, zejména monopolní postavení komunistické strany, reformu či systémovou změnu de facto neumožňovaly. ${ }^{39}$ Jak uvádí János Kornai, posilování samostatnosti podniků bylo projevem změny v hospodářském systému centrálně plánovaných ekonomik, mělo ovšem své limity - demokratická samospráva na úrovni podniku se nemohla v podmínkách politického monopolu komunistické strany plně rozvinout. ${ }^{40}$

33 Michal Macháček, Gustáv Husák (Praha: Vyšehrad, 2017), 486.

34 Zásady prebudování hospodářského mechanismu ČSSR: schváleno predsednictvem ÚV KSČ a vládou ČSSR. K otázkám přestavby hospodářrského mechanismu. Lubomír Štrougal, Miloš Jakeš: projevy na celostátním aktivu ÚV KSČ 27. ledna 1987 (Praha: Svoboda, 1987).

35 Směrnice k zabezpečení komplexní přestavby hospodářského mechanismu schválené na 7. zasedání ÚV KSČ 17. 12. 1987 a publikované v Usnesení vlády ČSSR č. 29/1988.

36 Zákon č. 88 ze dne 14. června 1988 o státním podniku, Sbírka zákonủ, částka 17 (1988), 461-474.

37 Výrobně hospodářské jednotky byly ustaveny v roce 1958 a představovaly třetí stupeň řízení centrálně plánované ekonomiky. Roku 1988 byly zrušeny a nahrazeny novými státními podniky. Poslední státní podniky zanikly až v roce 1990 .

38 Kalinová, Konec nadějím a nová očekávání, 206.

39 Otakar Turek, Podíl ekonomiky na pádu komunismu v Československu (Praha: Ústav pro soudobé dějiny AV ČR, 1995).

40 Kornai, The Socialist System, 464. 
Štrougal vyhodnotil konec tzv. reálného socialismu takto: „Jakékoliv zásadní reformní návrhy byly soustavně odmítány. $V$ tom spočívá podstata politické porážky socialistického společenství v uplynulém 20. století.“"

\section{Stranické řízení ekonomiky z pohledu vrcholných orgánů KSČ}

Odborná literatura se tedy poměrně podrobně věnuje hodnocení vývoje československé ekonomiky a jednotlivých opatření, která vedení strany a vláda v této souvislosti učinily, anebo naopak nerealizovaly. Méně znám a v literatuře zastoupen je pohled na to, jak KSČ svou roli při řízení ekonomiky uplatňovala a vnímala.

Sebevnímání role strany je obsaženo v řadě stranických materiálů a podkladů. Stranická příručka o roli stranických organizací při zajištování výrobních úkolů zdůrazňuje rozdělení rolí, kdy „stranické orgány a organizace sjednocují jednotlivé druhy ř́zení socialistické ekonomiky a vtiskují jim jejich celkovézaměrení. Důsledně je orientují především k tomu, aby nedocházelo k projevưm subjektivismu k oslabování celospolečenských zájmů [...]. Přestože je komunistická strana rozhodujícím subjektem hospodářské politiky, nepréebirá na sebe odpovědnost prímého ř́zeni národního hospodářství a zasahování do práv vedoucích pracovníků. Stranické organizace proto respektují pravomoc a odpovědnost vedoucích hospodářských pracovníků. “42 Stranické organizace pak mají především ideovou, organizační, koordinační, kádrovou a kontrolní funkci. Koncem osmdesátých let měla organizace KSČ v podniku podle nového zákona o státním podniku především dvě funkce: za prvé představovala „politickéjádro pracovního kolektivu“, které sjednocuje úsili vedení a dalších složek působících v podniku. Za druhé pak organizace KSČ „uplatñujíprávo stranické kontroly vưči vedení státního podniku a orgánům podnikové samosprávy a zabezpečují uskutečňování kádrové politiky KSČ“.43

V následujícím textu představujeme na případech vybraných metodou omezené sondy př́iklad toho, jak svou roli v řízení naplňovaly a vnímaly, resp. zaznamenávaly vrcholné orgány strany. Takový postup umožňuje sledovat postup stranických institucí, jejich chápání instrumentů, které při řízení na své úrovni měly k dispozici, i to, nakolik se dařilo oddělit odbornou stránku praktického ř́zení ekonomiky, které nebylo v kompetenci strany, od strategického politického

\footnotetext{
41 Štrougal, Paměti a úvahy, 79.

${ }^{42}$ Eduard Pawera a kol., Stranické organizace a hospodářské vedení při zajištováni výrobních úkolì (Praha: Svoboda, 1985), 53-54. Veškerá zvýraznění jsou autorova.

43 Zákon č. 88/1988 Sb. o státním podniku, 461. Veškerá zvýraznění jsou autorova.
} 
směřování ekonomiky, jež KSČ naopak považovala za spadající do její výlučné kompetence. $V$ neposlední řadě také ukazujeme, jakou roli měly odborně ekonomické záležitosti a jakou stranicko-organizační a ideologické otázky a rovněž do jaké míry bylo vedení strany (a vlády) v př́stupech k daným otázkám jednotné.

\subsection{Instrumenty a postupy při utváření a realizaci koncepčních rozhodnutí}

Vedení strany postupně vytvořilo nástroje a postupy pro formování a realizaci koncepčních a politicko-organizačních rozhodnutí a opatření.

Př́iklad postupu vedení strany představuje „Soubor opatření k zabezpečení usnesení ÚV KSČ k úkolům a rozvoji strojírenského, elektrotechnického a hutního průmyslu po XVI. sjezdu KSČ“, přijatý dne 30. srpna $1984 .{ }^{44}$ XVI. sjezd rozhodl o modernizaci výrobní technické základny při zrychlení vědeckotechnického rozvoje, o zkrácení inovačních cyklů a lepším zapojení strojírenství do mezinárodní dělby práce. Ve dnech 17. a 18. dubna 1984 se konalo 10. zasedání ÚV KSČ, které projednalo mj. zprávu PÚV k úkolům a rozvoji strojírenského, elektrotechnického a hutního průmyslu po XVI. sjezdu KSČ a které směřovalo politiku ke „zprogresivnění plánu na rok $1984 .{ }^{45}$ Důvodová zpráva zahrnuje i odkaz na zasedání Rady vzájemné hospodářské pomoci (RVHP), to ale není použito jako návod pro strategii a postup, ale hraje spíše potvrzující a legitimizační roli politiky KSČ. ${ }^{46} \mathrm{Na}$ tomto základě vláda vypracovala materiál Soubor opatření, který obsahuje především odkazy na praktické otázky řízení ekonomiky. ${ }^{47} \mathrm{~V}$ obecnosti dané i charakterem dokumentu jsou zde obsaženy principy, jimiž se měla řídit odpovědná místa a činitelé při realizaci rozhodnutí. Jedná se v první části o „zprogresivněni“" prováděcího státního plánu hospodářského a sociálního rozvoje na rok 1984. Důraz se klade na vyhodnocování výsledků a včasné upřesnění plánu na rok 1985.

Nástroje a stupně organizační činnosti, které vedení KSČ používalo, prezentuje dále např. politicko-organizační zabezpečení (dále POZ) realizace významného programového dokumentu nazvaného „Soubor opatření ke zdokonalení soustavy plánovitého řízení národního hospodářství po roce 1980 “, který byl

${ }^{44}$ Usnesení vlády ČSSR ze dne 30. srpna 1984 č. 235 o opatřeních k úkolům rozvoje strojírenského, elektrotechnického a hutního průmyslu po XVI. sjezdu KSČ, schůze předsednictva ÚV KSČ dne 3. 9. 1984, bod 1, příloha IV, sv. P 116/84, fond Předsednictvo ÚV KSČ, Národní archiv.

45 Soubor opatření k zabezpečení usnesení ÚV KSČ k úkolům a rozvoji strojírenství, elektrotechnického a hutního průmyslu po XVI. sjezdu KSČ. Důvodová zpráva, schůze předsednictva ÚV KSČ dne 3. 9. 1984, bod 3, prŕloha III, sv. P 116/84, fond Předsednictvo ÚV KSČ, Národní archiv.

46 Ibid., 2.

47 Usnesení vlády ČSSR ze dne 30. srpna 1984 č. 235. 
přijat na zasedání PÚV KSČ. ${ }^{48} \mathrm{POZ}$ představuje hlavní nástroje a stupně organizační činnosti, které vedení KSČ využívalo. Předpokládalo provedení stranických aktivů a zpracování vlastních $\mathrm{POZ}$ na všech úrovních stranické struktury: počínajíc resorty přes výrobně hospodářské jednotky (VHJ) až po jednotlivé závody. Soubor opatření byl zařazen do systému stranického vzdělávání. Dále mělo proběhnout rozpracování $\mathrm{POZ} v$ rámci organizací Národní fronty $(\mathrm{NF})$, zejména Revolučního odborového hnutí (ROH), Svazu socialistické mládeže (SSM) a Vědecko-technické společnosti (VTS). Vposledku dokument definuje úkoly pro pracovníky v hromadných sdělovacích prostředcích. Potvrzuje se tak, že KSČ měla vypracován politicko-organizační mechanismus, který zahrnoval posloupnost jednotlivých kroků a škálu opatření, jež měla zajistit přenos instrukcí z centra až na úroveň podniků.

Navíc komunikace směrem dolů byla (s ohledem na rozsah činnosti a počty aktérů) poměrně rychlá. Zpráva příslušného IX. oddělení ÚV KSČ při praktickém převedení výsledků kontroly Ústřední kontrolní a revizní komise ÚV KSČ (dále ÚKRK) na Ministerstvu průmyslu ČSR (MP ČSR) stanovila typickou časovou posloupnost projednání a realizace relevantních závěrů: IX. oddělení mělo projednat závěry s ministerstvem průmyslu do 20. ledna 1988, následně se závěry měly zabývat stranické schůze (do 29. ledna 1988) a celozávodní konference na MP ČSR (do března 1988). IX. oddělení ÚV KSČ pak během druhého pololetí 1988 plánovalo zpracovat zprávu o realizaci přijatých závěrů. ${ }^{49}$ Strana tak měla funkční mechanismy, které umožňovaly integrovat nové koncepční a politicko-organizační prvky, na nichž se vedení shodlo, během tří měsíců do praxe na podnikové úrovni a na úrovni základních organizací.

\subsection{Centrální kontrola podřízených orgánů}

Názorné prŕíklady toho, jak se realizovala vedoucí úloha strany při řízení ekonomiky, nabízejí výsledky kontrol, které prováděla ústřední kontrolní a revizní komise, tradičně konzervativní a ideologicky orientovaná část stranického

48 Politicko-organizační zabezpečení usnesení PÚV KSČ vlády ČSSR k souboru opatření ke zdokonalení soustavy plánovitého řízení národního hospodářství po roce 1980, Usnesení 129. schůze předsednictva UV KSČ ze dne 1. 2. 1980, bod 7, sv. P 129/80, fond Předsednictvo ÚV KSČ, Národní archiv.

49 Politicko-organizační opatření IX. oddělení ÚV KSČ ke Zprávě z následné kontroly, jak komunisté - vedoucí pracovníci a stranické organizace na Ministerstvu průmyslu ČSR plní úkoly XVII. sjezdu KSČ a opatření přijatá ke zvyšování efektivnosti a kvality produkce pro potřeby vnitřního a zahraničního obchodu, předloženo předsednictvu ÚV KSČ dne 28. 12. 1987, bod 9, př́loha III/2, sv. P 54/88, fond Předsednictvo ÚV KSČ, Národní archiv. 
vedení. ${ }^{50}$ Dokumenty z kontrol ukazují, jaké byly priority kontrolních orgánů strany a kde tyto orgány spatřovaly nejlepší možnost ovlivňovat výsledky hospodářské činnosti. Záznamy ÚKRK tak dobře ilustrují formy uplatňování vedoucí úlohy, které zjevně hrály v praxi vedení KSČ významnou roli.

První př́iklad představuje kontrola toho, jak komunisté, vedoucí pracovníci a stranické organizace na Federálním ministerstvu hutnictví a těžkého strojírenství (FMHTS) plní závěry XVII. sjezdu. Od září 1987 do února 1988 ji prováděla ÚKRK ve spolupráci s odpovídajícím oddělením ÚV KSČ v oboru hutnictví železa. ${ }^{51}$ Celkovým cílem rozvoje $\mathrm{v}$ dané hospodářské oblasti byl přechod od extenzivního rozvoje k větší intenzifikaci hutnictví železa, s čímž se pojily investice, zvyšování produktivity a kvality, snižování spotřeby vstupů atd.

Východiskem materiálu je všeobjímající teze, že „stranické orgány a organizace převzaly stěžejní úkoly hospodářské politiky pod stranickou kontrolu. Orientovaly komunisty i ostatní pracovníky na správné pochopení vytyčených úkolů a zvládnutí jejich zabezpečování v podmínkách jednotlivých pracovišt. $\mathrm{K}$ jejich naplnění usměrňovaly postup hospodářského vedení, pracovních kolektivů, organizací ROH a SSM." 52

Materiál následně podrobně a často kriticky prezentuje klíčová hospodářská data charakterizující vývoj daného odvětví. Dokládá např́iklad, že hutnictví (vývoz válcovaného materiálu) nahrazuje nedostatečnou schopnost ekonomiky zvyšovat export do tzv. nesocialistických zemí. Referenčním bodem pro posuzování úrovně rozvoje oboru přitom není SSSR, ale Západ, označovaný jako „Vyspělý“. Stř́ílivě se uvádí, že i při splnění plánovaných úkolů bude ČSSR zaostávat za hutnicky vyspělými zeměmi.

$\mathrm{V}$ pořadí těch, komu je připisován dobrý výsledek práce, je v materiálu na prvním místě uváděna strana. Konstatuje se, že to „je i výsledek politicko-organizační činnosti stranických orgánů a organizací, vedoucích hospodářských pracovníků, aktivity a iniciativy pracujících“.53

${ }^{50}$ ÚKRK byl orgán volený sjezdem strany. Jeho úkolem bylo kontrolovat dodržování stanov a plnění usnesení nejvyšších orgánů strany, dozorovat hospodaření strany, vyřizovat vnitrostranické stížnosti, provádět disciplinární řízení a řešit členské otázky. Od 1971 do 1976 byl předsedou ÚKRK Miloš Jakeš, poté do roku 1983 Miroslav Čapka, následovaný Jaroslavem Hajnem.

51 Výsledky kontroly, jak komunisté - vedoucí pracovníci a stranické organizace na ministerstvu hutnictví a těžkého strojírenství ČSSR a na vybraných podřízených organizacích plní závěry XVII. sjezdu KSČ, zejména $\mathrm{z}$ hlediska intenzifikace a efektivnosti hutní výroby, zasedání předsednictva ÚV KSČ [datum neuvedeno, jedna př́loha datována 17. 3. 1988], bod 8, sv. P 67/88, fond Předsednictvo ÚV KSČ, Národní archiv.

52 Výsledky kontroly, prŕíloha III, 2-3.

53 Ibid., 5. 
Pro urychlení procesu intenzifikace je však nutné kvalitativní ukazatele plánu „zprogresivnit““. ${ }^{54}$ Materiál ve své hospodářsko-technické části podrobně prezentuje technicko-organizační otázky výroby, investic, plnění plánu atd. a jmenovitě uvádí vedoucí hospodářské pracovníky, kteří údajně mají odpovědnost za nedodržování konkrétních normativů.

V další, stranicko-organizační části následuje kritika stranických orgánů FMHTS a podřízených organizací (zde ovšem bez udání jmen) za to, že neuplatňují důsledně „právo kontroly“ hospodářských pracovníků a výsledků svých úseků, a dále je jim vytýkáno, že často pouze nekriticky berou na vědomí zprávy a ústní informace vedoucích hospodářských pracovníků a spokojují se s jejich výsledky.

Další předmět kontroly představuje vnitřní život strany s důrazem mj. na „zkvalitňování stranických řad“: v roce 1987 bylo podle materiálu přijato v Nové huti Klementa Gottwalda (NHKG, nyní opět nazývané Nová hut') 97 kandidátů, z toho 75 dělníků, přičemž podíl mladých do 35 let činil 83,3\% přijatých, členů SSM bylo pak mezi přijatými 71,6 \%. ${ }^{55}$ NHKG měla v té době 21300 zaměstnanců, z toho 1341 mistrů, organizovanost byla $22 \%$ (u vedoucích pracovníků činila $68,44 \%) .{ }^{56}$

Kontrolovalo se i plnění „Dopisu PÚV KSČ k prohloubení účinnosti boje proti porušování socialistické zákonnosti, morálky a disciplíny“, jednoho z nejdůležitějších stranických dokumentů své doby, jímž se musely stranické orgány a organizace všech stupňủ velmi závazně a v konkrétních termínech zabývat a následně i rrídit. ${ }^{57}$ Jednotlivé stranické orgány rozpracovaly dopis pro své podmínky a ÚKRK pak hodnotila jejich účinnost i míru plnění. Materiál pojednával o tom, jak stranické orgány zabezpečují „rozvoj masové politické práce a uplatňování vedoucí úlohy strany ve společenských organizacích“, a konstatoval nízkou náročnost některých stranických orgánů při hodnocení práce komunistů v ROH a SSM, pokud jde o jejich podíl na zajištování hospodářských úkolů a upevňování kázně. ${ }^{58}$

Dopis PÚV KSČ nabízí zajímavý pohled na velký institucionální a personální rozsah stranických struktur a orgánů, které kopírovaly strukturu oboru.

${ }^{54}$ Ibid., 5.

55 Ibid., 22.

56 Ibid., 25.

57 „Dopis PÚV KSČ stranickým orgánům a organizacím k prohloubení účinnosti boje proti porušování zásad socialistické zákonnosti, morálky a disciplíny“, Rudé právo, 19. dubna 1986, 3. Dokument reaguje na rostoucí dynamiku ve společnosti, spojenou mj. se sovětskou přestavbou a glasností (novou transparentností a veřejnou informovaností).

58 Výsledky kontroly, př́loha III, 5. 
Na samotném FMHTS pracovaly celozávodní výbor (dále CZV) a osm základních organizací strany (dále ZO KSČ), na Generálním ředitelství VHJ hutnictví železa (GŘ VHJ HŽ) měli vlastní ZO KSČ, v NHKG Ostrava-Kunčice působil podnikový výbor (dále PV KSČ), 11 CZV a 64 ZO KSČ. Ve VSŽ Košice pracovaly PV KSS, 12 CZV a 90 ZO KSS. ${ }^{59}$

V samotném aparátu FMHTS pracovalo 715 pracovníků (z toho 153 ve vedoucích funkcích); organizovanost byla $63,4 \%$ (ve vedoucích funkcích $97,8 \%) .{ }^{60} \mathrm{~V}$ GŘ VHJ HŽ bylo 373 pracovníků, z toho 79 ve vedoucích funkcích, a organizovanost dosahovala 41,5\% resp. $84,8 \%$. Požadované odborné vzdělání splňovalo na FMHTS 54,6 \% (vedoucích pracovníků 78,6 \%), takže zde byla nejvyšší organizovanost a nejnižší odborné vzdělání v celém oboru a ÚKRK tento stav kritizovala. Odborné vzdělání mělo na GǨ VHJ HŽ 82,3 \% pracovníků (97,5\% ve vedoucích funkcích) a v NHKG $88,4 \%$ pracovníků (ve vedoucích funkcích 89,2 \%). ${ }^{61}$ ÚKRK vyjadřovala nespokojenost ohledně míry dosažení vyššího politického vzdělání, které poskytovala Večerní univerzita marxismu-leninismu (VUML) a formou postgraduálního studia Vysoká škola politická ÚV KSČ (dále VŠP) ${ }^{62}$ : na FMHTS absolvovalo toto vzdělání pouze $33 \%$ vedoucích pracovníků, na GǨ VHJ HŽ 53,2 \% a v NHKG „cílevědomým působení stranické organizace a vedení podniku“ dosáhli tohoto vzdělání u 86 \% vedoucích pracovníků a $39,2 \%$ u mistrů. ${ }^{63}$

Za významný nástroj stranické práce je v materiálu považováno komplexní hodnocení pracovníků (hodnocení výsledků jejich práce, společensko-politické angažovanosti, charakterových a morálních vlastností), jež bylo prováděno v souladu s usnesením PÚV KSČ. Např. v košických VSŽ bylo na základě závěrů hodnocení vyměněno 32 vedoucích pro nezvládnutí úkolů a 95 pracovníků různých stupňů řízení bylo vyřazeno z kádrových rezerv. ${ }^{64}$

U mnohých vedoucích pracovníků ale byly uložené úkoly kritizovány jako př́liš obecné. Za důležitý ukazatel se považovalo budování kádrových rezerv. Např. v podniku NHKG bylo na počet 95 nomenklaturních kádrů (na úrovni krajského, městského a okresního výboru) zařazeno do kádrových rezerv

\footnotetext{
59 Ibid., 25.

${ }^{60}$ Ibid.

61 Ibid.

62 Večerní univerzita marxismu-leninismu představovala nejvyšší stranické vzdělání na okresní úrovni. Na celostátní úrovni bylo nejvyšší formou stranického vzdělání studium na Vysoké škole politické (VŠP), prrípadně postgraduální studium tamtéž. Vybraní pracovníci stranického aparátu studovali rovněž na Vysoké škole politické ÚV KSSS v Moskvě.

63 Výsledky kontroly, př́loha III, 26.

64 Ibid., 26.
} 
104 pracovníků, z nichž 79 mělo dělnický třídní původ, 103 byli členy strany, 95 mělo vysokoškolské vzdělání a 70 absolvovalo VUML. ${ }^{65}$

ÚKRK se vyjádřila i $\mathrm{k}$ práci stranických orgánů kontroly a požadovala lepší př́ípravu a větší soustředění na úkoly $\mathrm{v}$ oblasti vědeckotechnického rozvoje, efektivnosti a kvality výroby, upevňování pracovní a technologické disciplíny.

Výsledné hodnocení kontroly kritizovalo neplnění některých záměrů plánu a pomalou intenzifikaci v oblasti hutnictví železných kovů. Podle závěrů ÚKRK mají vedoucí pracovníci rezervy a nedostatečně se soustředí na modernizaci, intenzifikaci a úspory. Stranické orgány sice plní svou roli, ale nedošlo $k$,žádoucímu zvýšení stranického působení na intenzifikaci a efektivnost hutní výroby“. Oceněno bylo zlepšení kádrové práce a zlepšení politického (zdůrazněno na prvním místě), odborného a věkového složení vedoucích pracovníků. ÚKRK poukázala na to, že strana očekává jejich autentickou angažovanost a kritizuje je za to, že „v jejich metodách a stylu práce mnohde přetrvávají administrativní prŕístupy. Chybí jim kritičtější a věcnější argumentace v prosazování celospolečenských zájmů i vyšší náročnost na řízené pracovní kolektivy. Na potřebné úrovni není jejich kontrola, kritika a sebekritika. To vede u některých $\mathrm{z}$ nich $\mathrm{k}$ pomalé adaptaci na současné úkoly hospodářské politiky strany.“66

Další variaci na téma řízení ekonomiky a kontroly plnění stranických normativů nabízejí dokumenty o následné kontrole, kterou ÚKRK provedla v ministerstvu průmyslu (MP ČSR) v roce 1987; šlo o vyhodnocení závěrů kontroly ÚKRK z roku 1984. ${ }^{67}$ Kontrola konstatovala řadu nedostatků v řídící a organizátorské práci komunistů - vedoucích pracovníků MP ČSR, zejména v uplatňování vědeckotechnického pokroku do praxe. Poukázala na neplnění úkolů plánu za léta 1986-1987 a na „ohrožení celé 8. pětiletky v resortu“, přičemž příčiny spatřovala v zaostávání technické základny a trvalém úbytku pracovníků v lehkém průmyslu, v poklesu cen při vývozu ropných produktů, ale i v nedostatečné úrovni „koncepční, řídící a plánovací činnosti vedoucích pracovníků resortu“.68 Nedařilo se tudíž splnit úkol československé vlády z roku 1984, aby byl problém nedostatkovosti zboží na vnitřním trhu vyřešen do roku 1988. ÚKRK rovněž

65 Ibid., 27.

${ }^{66}$ Ibid., 31.

${ }^{67}$ Zpráva z následné kontroly, jak komunisté - vedoucí pracovníci a stranická organizace na Ministerstvu průmyslu a obchodu ČSR plní úkoly XVII. sjezdu KSČ a opatření přijatá ke zvyšování efektivnosti a kvality produkce pro potřeby vnitřního a zahraničního obchodu, schůze předsednictva ÚV KSČ [datum neuvedeno, pravděpodobně prosinec 1987], bod 9, př́loha III/I, sv. P 54/88, fond Předsednictvo ÚV KSČ, Národní archiv.

68 Ibid., 3. 
zjistila, že vývozní produkce zaostává svou úrovní v porovnání s analogickými ukazateli průmyslově vyspělých zemí a dosahuje tak podstatně nižších kilogramových cen. ${ }^{69}$ Tím se dále prohlubovala negativní tendence, kdy investice nesměřovaly dostatečně do oblasti modernizace a rekonstrukce.

Dosud uplatněna nebyla ani opatření vyplývající ze závěru 8. zasedání ÚV KSČ směrem k posílení mzdové diferenciace tvůrčích pracovníků. Hlavní přičinu viděla ÚKRK $v$ tom, že „proti rovnostářství v odměňování nebojuje většina vedoucích hospodářských pracovníkủ “. ${ }^{70}$ Konstatovala, že šest organizací ministerstva průmyslu přešlo $\mathrm{v}$ roce 1987 na podmínky tzv. komplexního experimentu (např. VHJ Crystalex a Jablonecká bižuterie), v důsledku čehož se v nich zvýšila aktivita na všech stupních řízení, zároveň ale narostla administrativa při vykazování výsledků experimentu.

Opatření stranické organizace, která reagovala na kontrolu z roku 1984, „směřovala především k posílení politických prrístupů při hodnocení hospodářských výsledků, zvyšování úrovně politicko-organizátorské a ideově-výchovné práce, zkvalitňování členské základny a znáročnění stranické kontroly“. ÚKRR nicméně shledala, že „rozhodný obrat v účinnosti stranické práce na ministerstvu dosud nenastal "71 a že se nedaří dostatečně zvyšovat úlohu a účinnost členských schůzí ZO KSČ a zasedání CZV KSČ. ÚKRK vyčetla např. CZV KSČ, že na svém zasedání 27. července 1987 dostatečně nevyužil kritické připomínky, které k aktivitě celozávodního výboru přednesl ministr Hojer, že CZV pouze „obecně uložil všem výborům ZO KSČ, v prŕípadě neplnění úkolů ze subjektivních prŕíčin přijímat stranické závěry vůči zodpovědným komunistům, avšak nikdo dosud nebyl volán ke stranické odpovědnosti“.72

V ideologické práci požadovala ÚKRK hlubší osvojování stranických dokumentů tak, aby jejich studium pozitivně působilo na změny v chování a postojích komunistů při zajištování hospodářských úkolů resortu. Akcent se kladl opět na „zkvalitňování členské základny“ a zejména na růst organizovanosti. Od minulé kontroly se ji podařilo zvýšit o 6,3 procentního bodu; na ministerstvu průmyslu tak dosáhla $58 \%$, přičemž $55 \%$ členů vstoupilo do strany po roce $1970 .{ }^{73}$

Kritizována byla stranická organizace pro malé nároky, které CZV kladl na práci komunistů ve společenských organizacích, zejména v SSM, který se podle ÚKRK nedostatečně orientoval „na prosazování úkolů vědeckotechnického

\footnotetext{
${ }^{69}$ Ibid., 8.

${ }^{70}$ Ibid., 11.

71 Ibid., 17.

72 Ibid., 19.

${ }^{73}$ Ibid., 20.
} 
rozvoje a odhalování nedostatků v činnosti ministerstva formou Reflektoru mladých“" ${ }^{74}$ Tématem byla rovněž činnost celozávodní kontrolní a revizní komise, kdy ÚKRK došla k závěru, že kontrolní akce jsou zakončovány jen „dílčími zprávami na úrovni ZO KSČ a bez celkové analýzy, závěrů a opatření", a jen výjimečně se zprávám věnuje CZV KSČ. Kritická poznámka patřila i aparátu ÚV KSČ: ÚKRK požadovala, aby příslušné oddělení ÚV KSČ kladlo „mnohem vyšší náročnost na práci stranické organizace na ministerstvu i na činnost komunistů - vedoucích pracovníků “"75

Závěrem kontroly bylo, že „účinnost plnění opatření z roku 1984 se v podstatě neprojevila“, naopak resort v letech 1986-1987 přestal plnit státní plán. ${ }^{76}$ Mezi důvody ÚKRK uváděla „rozdílné názory mezi plánovacími orgány a vedením ministerstva na reálnost a potřeby komplexního zabezpečení úkolů 8. pětiletky“, nedostatečnou úroveň řídících článků resortu, subjektivní prííčiny a to, že plnění opatření přijatých k závěrům prověrky z roku 1984 ke stranické práci jen částečně napomohlo k aktivizaci a odpovědnosti komunistů při zabezpečení hospodářských úkolů. Závěrečná doporučení vyjmenovala věcné problémy a vyzvala obecně $\mathrm{k}$ „překonání negativních tendencí a obnovení dynamiky výroby, její kvality a efektivnosti“ a k „řešení zásadních strukturálních změn, urychlení vědeckotechnického pokroku“. ÚKRK dále požadovala „s přestavbou hospodářského mechanismu zásadně změnit styl a metody řídící a kontrolní práce“, „podstatně zvýšit nároky na kádry“ a nakonec „výrazně zkvalitnit úroveň politicko-organizátorské, ideově výchovné, kádrové a kontrolní práce CZV a ZO KSČ na ministerstvu“.77

Následná zpráva př́islušného IX. oddělení ÚV KSČ kladla ve srovnání se zprávou ÚKRK zjevně větší důraz na ekonomické faktory a podmínky, za nichž resort funguje, i když uznávala i nedostatky ve stranické práci. Úkoly, které na základě kontroly stanovila, se pak zaměřovaly primárně na ekonomické faktory a jejich řešení členy strany ve vedení MPO.78

${ }^{74}$ Ibid., 21. Reflektor mladých byla centrálně iniciovaná aktivita SSM, prováděná zejména na úrovni základních organizací na pracovištích a v místech bydliště. Cílem této akce, jejíž výsledky se pravidelně hlásily vyšším orgánům SSM a vyhodnocovaly se v ústředí, bylo odhalovat nevyužité rezervy, prríklady plýtvání zejména elektrickou energií a dalšími vstupy a zasazovat se o nápravu. V tomto smyslu měli členové SSM teoreticky kontrolovat a kritizovat i vedoucí hospodářské pracovníky čili vlastní nadřízené.

75 Ibid.

76 Ibid.

77 Ibid., 25.

78 Politicko-organizační opatření IX. oddělení ÚV KSČ, příloha III/2. 
Naopak opatření CZV KSČ na ministerstvu průmyslu, která se zabývají výsledky kontroly ÚKRK, zdůrazňují potřebu „klást důraz na stranické přístupy komunistů k zajištování úkolů " $v$ resortu, zvýšit účinnost stranicko-organizační a ideologické práce na všech úrovních, kádrové práce a kontroly. ${ }^{79}$

Kontrolu a následnou kontrolu provedla ÚKRK například také na Státní, České a Slovenské plánovací komisi. ${ }^{80}$ PÚV KSČ konstatovalo, že opatření přijatá na základě prověrky provedené ÚKSRK v roce 1983 byla převážně splněna. Tehdejší prověrka měla ke Státní plánovací komisi výhrady pouze administrativně byrokratického charakteru a týkaly se úrovně řízení ze strany vedoucích pracovníků, nikoli obsahových otázek plánování. Rovněž výtka nízké účinnosti stranické práce se týkala organizační činnosti; primárně se podle ÚKRK jednalo o nedostatečnou přípravu členských schůzí a o nízkou úroveň kontroly. ${ }^{81}$ Materiál poukázal na zlepšení stranické práce (př́ípravu schůzí ZO), nicméně podotknul, že se zvýšená úroveň členských schůzí a důslednější plnění úkolů vyplývajících ze zasedání ÚV KSČ „dosud dostatečně neodráží v kvalitě plánovací praxe a v rychlejším prosazování požadavků a potřeb intenzifikace národního hospodářství". ${ }^{82}$ I když se zlepšila ideologická práce, nedařilo se „důsledně spojovat obsahovou stránku ideologického působení s politicko-organizátorskou činností a řešením úkolů hospodářské politiky strany“. 83

Velká pozornost byla věnována kádrové práci: při celkovém počtu 943 pracovníků vzrostla organizovanost o 11 procentních bodů a dosáhla $70 \%$. Za důležité kritérium byl považován sociální původ, přičemž závěry kontroly konstatovaly, že se nedaří zastavit pokles počtu spolupracovníků dělnického původu (pokles o 1,8 procentního bodu na 54,9\%). ${ }^{84}$ Naopak vzrostl počet absolventů

79 Opatření CZV KSČ, CKRK a ZO KSČ PM ČSR k realizaci výsledků následné kontroly ÚKRK KSČ Jak komunisté - vedoucí pracovníci a stranické organizace na ministerstvu průmyslu ČSR plní úkoly XVII. sjezdu KSČ a opatření přijatá ke zvyšování efektivnosti a kvality produkce pro potřeby vnitřního a zahraničního trhu, schůze předsednictva ÚV KSČ dne 21. 12. 1987, bod 9, př́loha III/4, sv. P 54/88, fond Předsednictvo ÚV KSČ, Národní archiv.

80 Výsledky následné kontroly plnění opatření přijatých $\mathrm{k}$ dalšímu zdokonalování činnosti stranických organizací a zvyšování kvality práce Státní, České a Slovenské plánovacích komisí, Usnesení 25. schůze předsednictva ÚV KSČ ze dne 21. 1. 1987, bod 2, sv. P 25/87, fond Předsednictvo ÚV KSČ, Národní archiv.

81 Výsledky následné kontroly plnění opatření přijatých k dalšímu zdokonalování činnosti stranických organizací a zvyšování kvality práce Státní plánovací komise, Usnesení 25. schůze předsednictva UVV KSČ ze dne 21. 1. 1987, bod 2, př́loha III/a, 1-2, sv. P 25/87, fond Předsednictvo ÚV KSČ, Národní archiv.

82 Ibid., 3.

83 Ibid., 4.

${ }^{84}$ Strana kladla velký důraz na přijímání členů z řad dělníků, a to do té míry, že počet přijatých administrativních a řídících pracovníků často závisel právě na počtu přijatých dělníkủ a manuálně 
VUML a vyšších forem stranického vzdělání, a to z 14 na 213; dalších 26 pracovníků studovalo.

U takto centrálně sledované instituce se (na rozdíl od materiálu o FMHTS) uvádělo i ideologicko-bezpečnostní hledisko kádrové práce: odchodem do důchodu se snížil počet pracovníků se zrušeným členstvím z 92 na 53 . Zmíněn byl i počet pracovníků, jejichž prrímí příbuzní jsou v „kapitalistickém zahraničí“; ten poklesl z 19 na 13 a nikdo z nich nezastával vedoucí funkci. ${ }^{85}$ ÚKRK přiznala, že vyšší kvality práce se podařilo dosáhnout jen částečně.

\subsection{Pojetí role strany v ekonomice}

I když materiály PÚV KSČ a jeho Ústřední kontrolní a revizní komise kladly velký akcent na roli stranických organizací všech stupňů, orgány ÚV zabývající se bezprostředně hospodářskou problematikou věnovaly svou pozornost hlavně ekonomickým a organizačním aspektům vedení podniků. V roce 1988 předložil Jozef Lenárt materiál o systému podnikového hospodářství (SPH). ${ }^{86}$ Materiál zjevně hledal inspiraci pro zlepšení fungování státních podniků a zdůrazňoval samostatnost jednotlivých jednotek podniku, vysokou míru pružnosti v plánování, odměňování podle individuálního výkonu atd. Role strany se v materiálu, který čítal 89 stran, zmiňuje jen v podobě lakonického konstatování, že „při své činnosti se organizátoři [výroby - pozn. aut.] opírali o podporu stranické a odborové složky“. 87

V diskusi ke „Zprávě vlády ČSSR o stavu národního hospodářství ČSSR“ z 12. června $1989,{ }^{88}$ kterou na PÚV KSČ představil předseda vlády Ladislav Adamec, se projevil výrazný odstup vlády, ale také sociálně-ekonomického oddělení

pracujících. KSČ se takto snažila garantovat „dělnický charakter“ strany, jenž měl pro její politiku zvláštní legitimizační význam.

85 Výsledky následné kontroly plnění opatření přijatých k dalšímu zdokonalování činnosti stranických organizací a zvyšování kvality práce Státní plánovací komise, 6.

${ }^{86}$ Systém podnikového hospodářství (SPH) se uplatňoval v letech 1948-1952 a vyvinul se ze systému podnikové samosprávy, uplatňovaného ve znárodněných firmách známých vysokou úrovní organizace práce - především šlo o firmy Škoda a.s. Plzeň, Kolben-Daněk a.s. Ostrava, Bata a.s. Zlín, Bata Šimonovany.

87 Systém socialistického podnikového hospodárství uplatňovaný v podnicích období budování socialistického průmyslu v ČSSR. Charakteristika systému SPH - socialistického podnikového hospodářství, uplatňovaného v národném podniku Závody 29. augusta Partyzánské v rokoch 1946-1952. VHJ OGAKO, Jún 1988, 1, schůze předsednictva ÚV KSČ dne 6. 7. 1988, bod 7, sv. P 77/88, fond Předsednictvo ÚV KSČ, Národní archiv.

88 Zpráva vlády ČSSR o stavu národního hospodářství ČSSR, schůze předsednictva ÚV KSČ dne 12. 6. 1989, bod 1, sv. P 121/89, fond Předsednictvo ÚV KSČ, Národní archiv. 
ÚV KSČ i 9., 10. a 11. oddělení ÚV KSČ od pozic tvrdého jádra PÚV KSČ. 89 Uvedená oddělení ÚV KSČ Zprávu vlády v podstatě podpořila a měla $\mathrm{k}$ ní jen doplňující připomínky. ${ }^{90}$

Podle archivovaného kusého ručního zápisu diskuse na zasedání PÚV KSČ kritický prŕstup zprávy v podstatě odmítli Alois Indra, Josef Haman, Jan Fojtík nebo Miloš Jakeš; naopak v zásadě vstřícně reagovali například Gustáv Husák a Jozef Lenárt. Indra uvedl, že nemůže pochopit důvod (kritického) přístupu zprávy, a nazval ji „zdí nářkư “.91 Předseda vlády Adamec konstatoval, že „situace je vážná a nebudeme-li ji řešit, bude kritická“; uznal, že „nevíme, jaký bude vývoj v prríštích letech [...] a nemáme ani dostatek znalostí" ${ }^{92}$ Silně zazněla snaha udržet názorovou a tím také akční jednotu - Jakeš podle zápisu situaci shrnul tak, že „jakmile se zjistí, že jsou zde diametrálně odlišné názory, že se hádáme [...], to je konec, to je začátek mad'arského vývoje“. ${ }^{93}$

Skutečnost, že se v orgánech ÚV KSČ názory na hospodářské řízení diferencovaly, dokládá mj. zápis z jednání národohospodářské komise ÚV KSČ, vedené členem předsednictva ÚV KSČ Jozefem Lenártem, ze 17. května 1989. ${ }^{94}$ Předmětem jednání byly dokumenty „Analýza hospodářského a sociální rozvoje po XVII. sjezdu KSČ“ a teze $\mathrm{k}$ „Základním směrům hospodářského a sociálního rozvoje do r. 2005 a na 9. pětiletku“, které uvedl místopředseda Státní plánovací komise (SPK) Václav Věrtelár. Účastníci diskuse předloženou analýzu charakterizovali jako „materiál, který nedostatečně hledá příčiny nedostatků a chyb v minulosti, nejde do hloubky analýzy postupu přestavby, málo zdůrazňuje kontinuitu budování socialismu u nás a navržená opatření jsou zatím nekonkrétní a nedostatečná“. ${ }^{95}$ De facto chyběla apelační a ideologická poloha, tradičně př́ítomná v jiných materiálech ÚV KSČ, zejména PÚV.

Uvedená analýza vybraných dokumentů ústředních stranických orgánů potvrzuje pozorování Lubomíra Mlčocha o politické ekonomii socialismu: V uzavřeném hierarchickém systému (tedy systému, který neumožňuje objektivní

89 Záznam diskuse ze 121. schůze předsednictva ÚV KSČ dne 15. 6. 1989, sv. 121/89, fond Předsednictvo ÚV KSČ, Národní archiv.

90 Stanovisko sociálně ekonomického oddělení ÚV KSČ ke Zprávě vlády ČSSR o stavu národního hospodářství ČSSR, 121. schůze předsednictva ÚV KSČ dne 12. 6. 1989, bod 1, př́íloha II, sv. 121/89, fond Předsednictvo ÚV KSČ, Národní archiv.

91 Záznam diskuse ze 121. schůze předsednictva ÚV KSČ dne 15. 6. 1989, 25.

92 Ibid., 33.

93 Ibid., 36. Zvýraznění autorovo.

${ }^{94}$ Informace z jednání národohospodářské komise ÚV KSČ konané dne 17. května 1989, schůze předsednictva ÚV KSČ, bod 7, sv. P 118/89, fond Předsednictvo ÚV KSČ, Národní archiv.

95 Ibid., 4. 
pohled na ekonomiku, protože jsou všichni aktéři zájmově provázaní a vzájemně závislí) fungovala jakási „přací ideologie“ s řadou čistě utopických prvků: politická ekonomie socialismu se pěstovala jako „ideologie normativně pojatého racionalistického konstruktu nově uspořádané ekonomiky a společnosti“ “96

$\mathrm{Z}$ této logiky vycházely ty části stranického a státního aparátu, které řešily reálné fungování ekonomiky a informovaly vedení o skutečném stavu věcí. Politické vedení ale bylo rozdělené a pro zásadní řešení se rozhodnout neumělo. Reagovalo zdůrazňováním převážně obecných úkolů pro operativní hospodářskou činnost státních orgánů a konkrétních úkolů pro různé aspekty stranické práce.

V odlišných přístupech ekonomicky a politicko-ideologicky zaměřených osob a institucí vedení strany se projevovala diferenciace v pojetí role strany při řízení ekonomiky. Některé závěry navíc odrážely nejistotu ohledně schopnosti strany a jejích orgánů nějakou reálnou vedoucí úlohu strany realizovat (poukazovaly např. na projevy asymetrie ve prospěch vedoucích hospodářských činitelů v podnicích, kdy se málo zkušené stranické vedení často dostávalo do závislého postavení). Velkou pozornost přitom vedení strany věnovalo organizačním otázkám, včetně provádění stranických schůzí a hodnocení, ideové práci a přípravě kádrů (zvyšování kvalifikace a ideové výchovy) a přijímání nových členů. Zejména v ústředních orgánech byl kladen velký důraz také na „kádrovou čistotu“ strany (např. na vztah kádrů k roku 1968 nebo na styky se zahraničím). Naplňoval se tak záměr dosáhnout „soustavným zkvalitňováním a doplňováním“ členů KSČ „Zabezpečení vedoucí úlohy strany ve všech oblastech a místech života naší socialistické společnosti“. 97

\section{3. „Reality check“: stranické rízení ekonomiky z pohledu aktérů}

V následující kapitole shrnujeme výpovědi vybraných aktérů, kteří se v rámci projektu vyjádřili k otázkám řízení ekonomiky. Zahrnujeme přitom jak pohledy několika regionálních stranických funkcionářů, tak názory vedoucích hospodářských pracovníků. ${ }^{98}$

96 Mlčoch, Chování československé podnikové sféry, 215.

97 Směrnice ÚV KSČ k soustavnému zkvalitňování členské základny strany. In Sborník vybraných dokumentů orgánů KSČ (Praha: Svoboda, 1977), cit. dle Hradecká a Koudelka, Kádrová politika a nomenklatura KSČ, 45.

98 Výběr z celkových 75 rozhovorů projektu GAČR. Rozhovory vedl (kromě respondentů č. 1 a 2 ) sám autor; rozhovory jsou nahrány a přepsány v databázi projektu. Pro účely studie byly rozhovory anonymizovány. 


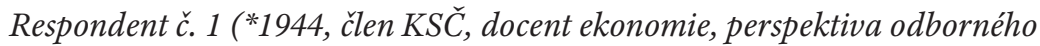
pracovníka Státníplánovací komise)

Respondent jakožto pracovník pomyslného „centra“, tedy člověk, který prošel Státní plánovací komisi od pozice referenta po náměstka předsedy, nabízí vhled do funkčních vztahů mezi podniky a částí aparátu zaměřeného na státní plánování ve vazbě na produkci pro zahraniční obchod. Státní plánovací komisi (SPK) chápe jako centrální orgán, který byl v zásadě autonomní a relativně imunní vůči politickým tlakům a spolu s Prognostickým ústavem se pohyboval spíše $\mathrm{v}$ rovině odborně-byrokratické. Jako hlavní funkci SPK ve vztahu k podnikům identifikuje respondent koordinaci ročních plánů. Tyto plány, které schvalovala vláda, určovaly mezinárodní hospodářskou spolupráci (především se zeměmi RVHP), v prvé řadě míru vývozu. „To znamenalo, že se zeměmi RVHP se dohadovaly položky vývozu a dovozu, položka po položce.“ Taková spolupráce vedla k závěrečné - většinou pozitivní - platební bilanci, které bylo místy třeba „dopomoci“, ale v líčení respondenta se v podstatě nejednalo o politické rozhodování. Centrum - mimo jiné Státní plánovací komise v součinnosti s vládou tak předávalo jednotlivým podnikům údaje o předepsané výrobě a stanoveném vývozu; byla to „ilustrace direktivního řízení“, podle respondenta řízení méně citlivého a více byrokratického než v prrípadě podniků zahraničního obchodu. Politická moc, kterou respondent explicitně nespojuje s KSČ, do jednání vstupovala $\mathrm{v}$ rovině důležitých cílů. Na konci roku probíhalo v komisi zhodnocení veškerých projektů spolupráce, naplnění předpokladů o výrobě, vývozu apod.

Respondent líčí Státní plánovací komisi jako orgán odborný, relativně uchráněný politických vlivů, problematický spíše jako byrokratická instituce, která např́klad omezovala „přirozený“ rozvoj podniků a byla někdy nucena požadovat po nich takovou produkci, která by naplnila cíle stanovené státem, tj. „politicky“. Respondent se pohybuje spíše v diskurzu (ne)odbornosti a v této rovině hodnotí rovněž drobné ohlasy perestrojky - jako omezené „oživeni“ pracovních vztahů a nástup „odbornějších diskusí“ do jednání. Momenty vstupu „politiky“ líčí spiše jako politickou objednávku po ekonomickém růstu a v oblasti mezinárodního obchodu také nutně v otázce vývozu do kapitalistických zemí. Samotní pracovníci Státní plánovací komise jsou nicméně líčeni jako vesměs „chránění“. Jakkoli bylo centralizované rozhodování zatíženo řadou problémů, respondent explicitně neuvádí významný vliv KSČ, pouze vágní „politické vlivy“ v rovině objednávky cíle (růstu, exportu, určité platební bilance) s tím, že konkrétní cesty $\mathrm{k}$ jejich dosažení byly vesměs $\mathrm{v}$ rukou odborných pracovníků komise, podniků zahraničního obchodu, do jisté míry také Prognostického ústavu, s nímž komise rovněž spolupracovala. 
Respondent č. 2 (*1954, nestraník, Ing., vedouci technický pracovník, perspektiva podniku)

Respondent identifikuje především tlak na ekonomickou výnosnost ze strany vedení podniku. Pokud jde o vliv shora, zmiňuje ho jako většina respondentů především v souvislosti s přidělováním financí („shora“, př́ímo z rozpočtu nebo z fondů, které byly pod politickou kontrolou). To se týká jak mzdových prostředků, tak naprríklad rekreací a dalších sociálních programů, které měly v gesci odbory. Šéfové odborů, jak uvádí, ostatně „byli na úrovni ředitelü“, a určovali, kdo kam vyjede apod.

Velký společný projekt, který byl nařizován shora, ale na úrovni podniku úzce souvisel s místními odbory a se vztahy $\mathrm{v}$ podniku, představovaly brigády socialistické práce. Respondent zavrhuje, že by aktivita zaměstnanců nebo organizaci práce v brigádách zásadně souvisela s členstvím v KSČ. Členy KSČ v podniku charakterizuje jako samostatnou, do jisté míry oddělenou skupinu lidí rozprostřených po podniku, skupinu, která žila „svým vnitřním životem“.

Nicméně podle respondenta měla KSČ obecně v životě podniku zásadní roli. Jeho vedení se zodpovídalo straně; předseda stranické organizace měl moc srovnatelnou s ředitelem podniku. Stranická organizace měla přímou vazbu na centrální KSČ. Právě z centra přes centrální organizaci šly k řediteli stížnosti ohledně plnění plánu apod. Ředitel byl rovněž členem KSČ a byl současně nadřízeným zaměstnanců - členů stranické organizace, takže se jednalo o dvojaký vztah. Ředitelé se v rámci podniku zodpovídali jednak generálnímu řediteli, jednak straně. Častěji šla proto řeč o „dvojvládí“. Členství v KSČ přitom bylo navázáno na vyšší funkce - nejen na funkce ředitelské, ale někdy také na vysoké funkce $\mathrm{v}$ technologickém provozu. Pokud jde o členství v KSČ obecně, respondent tvrdí, že v průběhu osmdesátých let začalo více lidí vstupovat nejen proto, že to vyžadovala kýžená funkce, ale také proto, že viděli prostor pro vnitřní proměnu strany. $\mathrm{V}$ tomto měla jednoznačně sehrát roli přestavba: ekonomické reformy v Sovětském svazu vytvořily naději, že lze věci měnit, že lze „něco zlepšit, že [se] budeme mít [...] dobře jako kapitalisti vedle, že budeme více tržní“. Více lidí mělo v návaznosti na Gorbačovovu politiku myslet „více ekonomicky a méně politicky“. Mluví ale spíše o jisté náladě, konkrétních opatření mnoho neidentifikuje. Rovněž u dalších respondentů nenacházíme odkazy na žádnou výraznější celostátní politiku v tomto směru. Zaváděly se nicméně dílčí, do jisté míry tržní experimenty na úrovni jednotlivých podniků, což více rozvádějí naprríklad respondenti č. 4,5 a 6 . 
Respondent č. 3 (*1947, člen KSČ, vyučený valcír, perspektiva závodu a odborové organizace Válcoven plechu)

Respondent pracoval přibližně 30 let na ostravské Nové huti, která patřila $\mathrm{k}$ výstavním, $\mathrm{v}$ republice zcela zásadním podnikům, jež po většinu let plnily nebo dokonce překračovaly plán. Plán, jak již bylo uvedeno, přicházel shora od vlády a od Státní plánovací komise. Výrobně hospodářské jednotky, vytvořené při reorganizaci československého hospodářství v roce 1958, plán následně rozepsaly na jednotlivé podniky, v podniku se dále rozděloval mezi jednotlivé závody. Na nejvyšší úrovni toto prováděl podnikový výbor strany, který spolu s hospodářským vedením rozepisoval plán na jednotlivé části podniku, na měsíce, dny, někdy dokonce i hodiny, což respondent uvádí jako svou zkušenost z válcovny. V souvislosti s plánem se kontrolovala efektivita výroby; další složkou byla motivační složka platu a soutěž mezi závody. Plán ale nebylo možné jakkoli rozporovat; dynamika $\mathrm{v}$ tomto ohledu nebo např́iklad $\mathrm{v}$ alokaci peněz na mzdy šla shora dolù.

Pozoruhodný moment představuje pro analýzu fungování centrálně plánované ekonomiky požadavek navýšení výroby ve čtvrtém čtvrtletí, který prosadil krajský výbor strany; byl to prvek výlučný pro Severomoravský kraj. ${ }^{99}$ Jednalo se podle respondenta o závaznou direktivu, která severomoravským podnikům nařizovala navýšit ke konci roku výrobu, aby se přiblížily plánu na rok následující. Podnikový aktiv opět rozepisoval potřebné výkony na jednotlivá pracoviště podle jejich možností a zajištoval, co bylo pro takový výkon nezbytné, ale na samotné rozhodnutí neměl valný vliv. Toto zvyšování výkonu ke konci roku, tedy jakési předběžné plnění plánu na rok následující, se vžilo mj. pod pojmem „Mamulovy soboty" podle dlouholetého krajského tajemníka na Ostravsku Miroslava Mamuly a přestavovalo přímý vstup KSČ do plánování výroby. Tento „dodatek“ k plánu nepřicházel od vlády ani Státní plánovací komise, ale od krajského výboru KSČ. Strana tak vstupovala do hospodářského cyklu a vynucovala si určitou míru nadvýroby. Podniky přitom měly na krajském výboru své zástupce, respondent ovšem uvádí, že jich (za Novou hut') bylo tak málo, že to nemělo velkou váhu. Tyto postupy v zájmu tzv. „Zabezpečováni“ hospodářských úkolů (tedy z krajské úrovně, ale v zájmu úkolů shora) se týkaly především velkých podniků - v nemalé míre tedy Nové huti jako jednoho z největších podniků v republice.

Co týden se v podniku konala setkání s řediteli závodů, náměstky, zástupci Státní plánovací komise, a pokud se nedařilo plán plnit, mobilizoval se

99 Severomoravský kraj, který jako územní jednotka dodnes existuje, ale nemá žádné správní orgány, je rozlohou dvakrát větší než dnešní Moravskoslezský kraj. 
funkcionářský aktiv podniku, hospodářští pracovníci a podobně. Na těchto poradách měly pochopitelně zastoupení také stranická a odborová organizace.

Pokud jde o perestrojku, respondent žádné výraznější posuny nezaznamenal. Rozhodování v podniku bylo nadále třístupňové (na rovině podniku, závodu a provozu) a úrovně nad nimi, jako byly centrální plánovací orgány, krajská stranická organizace, vláda apod., se z jeho perspektivy př́liš neměnily. Z centra přitom trval a spíše sílil tlak na stále intenzivnější výrobu.

Kraj současně za všeobecného pracovního podstavu spravoval také pracovní trh, tj. přiděloval pracovníky. Pokud jde o personální otázky - např́klad propouštění -, hrály zde významnou roli odbory, které byly poměrně silné. Podle respondenta byl obecně pro spory a vůbec pro komunikaci mezi pracovníky a různými patry vedení stěžejní podnikový výbor strany, který „přijímal kandidáty, velel lidovým milicím a tak dále“. Podnikový výbor fungoval v partnerství s podnikovým výborem $\mathrm{ROH}$ a hospodářským vedením; předsedové těchto orgánů se scházeli vždycky v pondělí, zhodnotili týden, stanovili cíle na příští týden a radili se o plnění plánu. Na závodní úrovni působil celozávodní výbor strany, „tam byl ředitel nebo vedoucí závodu, předseda odborové organizace a ten svazák“. Jednalo-li se o zásadní otázku, orgány zasedaly a probíraly ji společně, přijímaly se závěry, které pak v rámci hierarchie putovaly k provozům. Na provozech fungovaly dílenské výbory, základní organizace a tak dále, ty ale byly podřízeny stranickým a spř́izněným orgánům na závodní a podnikové úrovni.

$\mathrm{V}$ príípadě, že byl řídící pracovník vyloučen ze strany, mohl se vrátit do funkce technické, ale nikoli řídící. Členy strany museli být ředitel a náměstci, na nižších patrech mohli být lidé se zrušeným členstvím. V tomto ohledu se mnoho neměnilo ani s ozvuky sovětské přestavby.

Pokud jde o úlohu odborové organizace, na Nové huti se soustředila v prvé řadě na zajištění stravování pro všechny pracovníky na směně a na další sociální programy. Respondent uvádí programy poskytující půjčky, právní pomoc, fond kulturních a sociálních služeb a pochopitelně podnikovou rekreaci. Odborová organizace se tak starala o bezpečnost práce, hospodářský výkon nebo sociální otázky, organizovala práci např. v rámci brigád socialistické práce. Nevěnovala se kádrům, „kádrová práce byla pro partaj“.

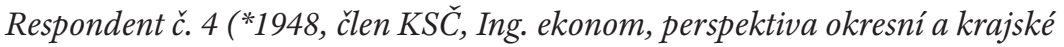 stranické organizace KSČ na severní Moravě)}

Respondent působil jako předseda okresní frýdecko-místecké organizace KSČ, která byla součástí stranického aparátu největšího kraje jak co do počtu obyvatel, tak co do ekonomického výkonu. Jako představitel strany v takto silném 
regionu „měl otevřené cesty $\mathrm{k}$ předsedům vlád, ministrům českým i federálním a tak dále“. S centrem se jednak komunikovalo „po té stranické linii okresní, krajský výbor, ústřední výbor", a to přes členy ÚV a prostřednictvím písemných materiálů, jednak vedle toho fungovala linie „hospodářská“. Na krajských stranických orgánech se probírala výroba a řešily se zde problémy, protože těchto jednání se mnohdy účastnili ministři nebo náměstci ministrů.

Hierarchie na okresní úrovni byla následující: „nejvyšší orgán okresu byl okresní výbor a předsednictvo okresního výboru“, jednou za čtvrt roku probíral problémy s okresním národním výborem. Neřešil se ani tak velkoprůmysl jako bytová výstavba, potravinářství, školství, doprava apod. Stranický orgán měl tedy na starosti strategické otázky a měl silnější vazbu na centrum, zatímco národní výbor spíše dohlížel na „komunální politiku“, byl spíše lokálně ukotven. Podnikové plány přitom procházely kontrolami a okresní, krajské a další stranické a odborové orgány „konzultovaly spís ty obrysy, konzultovali jsme rozvoj celého toho odvětví v rámci kraje [...]. Ale do té bezprostřední tvorby ani komunistická strana ani odbory jaksi bezprostředně nezasahovaly.“

Respondent uvádí, že od podniků existovalo napojení na centrum (například generální ředitel byl současně členem předsednictva krajského výboru strany, generální ředitel Vítkovic zase členem ústředního výboru), nicméně podnikové plány se konzultovaly spíše na úrovni oddělení. Stranické orgány výrazně nezasahovaly, respektive sledovaly plán jako celek, do detailů ho ale nerozebíraly. Zásadní byly tedy objem výroby a sledování dlouhodobých plánů. Pokud nebyl plán plněn, řešila to strana na podnikovém výboru za účasti odborů a na okresních výborech; respondent $\mathrm{k}$ tomu zavedl porady ekonomických náměstků ústředně řízených podniků - což nebyly zdaleka všechny podniky, jen okolo sta podniků v republice - jednou za půl roku. Připouští, že se do jisté míry jednalo o „systém tlaku“ nebo - z jeho pohledu spíše - „výchovy“ náměstků jednotlivých podniků; v tomto případě lze mluvit o větší míre zasahování, nebot stranický orgán $v$ těchto př́padech vstupoval do provozních záležitostí podniků poměrně výrazně. Jinou formou tlaku ze strany kraje byly již zmíněné „Mamulovy soboty“.

$\mathrm{Na}$ kraji respondent působil na oddělení kádrovém a politicko-organizačním, které se věnovalo vnitřnímu životu strany. Je ale důležité, že působil nejen $\mathrm{z}$ centra vi̊či podnikům, ale také naopak: $\mathrm{v}$ př́ípadě potíží s plněním plánu byla stranická linie jedním z kanálů komunikace s centrem, např. při vysvětlování, že současný plán je nereálný.

Pokud jde o loajalitu na místní úrovni, případně vůči centru, respondent tvrdí, že záleželo především na jednotlivcích, na vztazích mezi lidmi a na jejich 
schopnosti sledovat objektivní, sdílený cíl (hospodářský výkon, překročení plánu). Respondent uvádí příklad, kdy krajský tajemník zajistil, že ministři, kteří přijeli zkritizovat místní ředitele za špatnou práci, pochopili složitosti provozu; podle něj tedy krajská a okresní stranické organizace mohly nejen tlačit z podnětu centra podniky $\mathrm{k}$ vyšším výkonům, ale také naopak pomáhat při komunikaci s centrem. Miroslav Mamula byl podle respondenta velký zástupce strany i regionu, schopný kýženého objektivního úsudku, na jakém se mělo zakládat socialistické hospodářství.

V osmdesátých letech, kdy docházelo k omezené modernizaci, se respondent věnoval kádrové práci. Vzhledem $\mathrm{k}$ tomu, že cílem bylo dostávat do funkcí mladší lidi, věnovala se větší pozornost kádrovým programům. Mladí měli být „připraveni odborně, připraveni i politicky“. Respondent uvádí, že cítili, že „dynamika toho rozvoje je menší a že [by] prostě [...] bylo třeba ty věci posouvat dál“, pochopitelně ale ve spojení s pečlivou přípravou kádrů. Pokud jde o stranické orgány, tam byly kádrové pořádky, které určovaly funkce v nomenklatuře, které se periodicky vyhodnocovaly, spojovaly se s určitými úkoly, kompetencemi, vzděláním apod. Toto bylo v principu podobné na všech úrovních, ačkoli na úrovni okresu nebo podnikových výborů se jednalo spíše o seznamy funkcí, které byly pod větším (stranickým) dohledem a jejichž nositelé mohli být stranou voláni k odpovědnosti nebo, častěji, $\mathrm{k}$ vysvětlení. $\mathrm{V}$ kádrových pořadnících byli i nestraníci; respondent tvrdí, že „nikde nebylo a není řečeno, že ve funkci ředitele Nové huti musel být člen strany“. Připouští ale, že se častěji vybírali komunisté. $V$ menších podnicích a ve funkcích náměstků podle něj nestraníci figurovali. Za perestrojky potvrzuje především silnější tlak na odbornost a omlazení kádrů v řídících i čistě stranických funkcích.

Závodní či podnikový výbor strany, př́ípadně $\mathrm{ROH}$ vytvářely politické prostředí, $v$ podstatě politický dohled. Na této půdě se řešily nastávající problémy (personální politika, vnitropodnikové vztahy apod.) a rovněž ve vztahu k plánu platily spíše za dozorový orgán. Vyšší patra (okres, kraj) do práce těchto útvarů vstupovala, účastnila se setkání, zasahovala ve chvíli, kdy bylo třeba někoho (napřr. ředitele) „usměrnit“ nebo „vychovat“. V př́ípadě, že komunikace nefungovala dlouhodobě a problémy se neřešily, byli lidé z funkce odvoláni.

Odbory měly na starosti rekreaci, bezpečnost práce, zákoník práce, výchovu. Jejich předseda byl členem stranického orgánu, tudíž se odbory vyjadřovaly i k plánu. Mezi jednotlivými složkami byla podle respondenta funkční dělba práce.

Důraz klade na součinnost stranických, hospodářských a odborových orgánů, kterou považuje za převážně dobrou, koordinovanou; stranicko-odborovou 
a hospodářskou rovinu nepovažuje za dvoukolejnou a pro hospodářský výkon neštastnou. $V$ př́padě, že taková dvojkolejnost nastala, vysvětluje ji spíše osobními neshodami, animozitami, př́padně lidskými nedostatky. Zdůrazňuje, že všechny složky, resp. stranický orgán, hospodářské vedení, odborový a svazácký orgán, byly propojeny např. členstvím ve straně a setkávaly se. Přesto měla stranická rovina navrch v př́ípadě „řešení problémü“ už proto, že měla hlavní slovo v kádrových, personálních otázkách.

\section{Respondent č. 5 (*1956, člen KSČ, JUDr., Národnívýborv Ostravě, perspektiva regionální správy)}

Respondent působil ve vícero funkcích, ale nejpodstatnější pro naše téma je funkce tajemníka Národního výboru Ostravy 1. V tehdejším Severomoravském kraji „působil Krajský národní výbor, Národní výbor města Ostravy, okresní národní výbory a v rámci Ostravy jako statutárního města byly čtyři obvodní národní výbory, které měly svoje vlastní hospodářstvi“. Pracovníci národního výboru bývali podle respondenta současně členy okresní stranické organizace, stranické orgány se formovaly podle orgánů národního výboru a naopak, tajemník národního výboru býval šéfem stranické organizace apod. Tajemník národního výboru byl „personální šéf“ nad odbory národního výboru, kterých bylo okolo deseti: Agendu, která stála nad jednotlivými odbory, řešily řídící orgány (městská rada, rada městského obvodu), a ty také byly v řídící pozici vůči hospodářským jednotkám.

Ze správních orgánů byly vůči centru nejsilnější krajské národní výbory: měly silnou vazbu na Státní plánovací komisi a ministerstva, měly tedy jistou byt' omezenou - možnost ovlivňovat plánování, finanční limity apod. Tuto možnost neměly okresní, městské ani další národní výbory, a to ani při postupné, mírné decentralizaci a posilování okresních a vůbec nižších úrovní státní správy, jak bylo možné pozorovat $v$ průběhu osmdesátých let. Místní národní výbory vznášely pochopitelně požadavky, centrum je ale nemuselo brát v potaz, navíc byly limitovány přidělenými finančními prostředky. Centrum, zejména Státní plánovací komise, tak především stanovovalo politické zaměření, zadání. Pokud jde o vedení podniků, národní výbory měly „pod sebou“ spíše komunální podniky, nikoli klíčové podniky v kraji, na kterých závisel státní plán. Komunikace ohledně zajištění státních plánů, př́ípadně ohledně usnesení sjezdů mezi jednotlivými proudy a patry tehdejší rozhodovací struktury, jak ji respondent definoval, opět vyznívá poměrně komplikovaně a vykazuje sklony k paralelnímu řízení: „komunikace šla dvojí linií, čili deváté oddělení ÚV strany s ministerstvem pro hutnictví a strojírenství projednávalo [zajištění plánů, realizace usnesení apod.], 
po státní linii se to dostalo do státních podniků a po stranické linii se to dostalo [...] na ty krajské výbory strany“. Shromažd'ování komunikace měl na starosti politicky organizační odbor se svým tajemníkem, ten ale pouze sbíral informace, byl to „odbor svodný“, který nezodpovídal za samotnou ekonomiku.

\section{Respondent č. 6 (*1952, člen KSČ, Ing. RSDr., perspektiva aparátu strany} na úrovni ÚV KSČ)

Respondent líčí stranicko-ekonomické konference jako poměrně významný orgán a moment $\mathrm{v}$ rozhodování. Scházelo se zde hospodářské vedení se stranickými organizacemi a spolu pak probíraly, jak naplnit plán, jak zabezpečit výrobu apod. Pokud se objevil problém, hospodářské vedení dostalo za úkol pokusit se vyjednat změnu ve vyšších patrech hospodářského rozhodování. Pokud se došlo ke shodě, stranické orgány dostaly za úkol zmobilizovat síly a zabezpečovat plnění plánu. Podle respondenta bylo zásadní rovněž personální propojení. Např́íklad Zdeněk Krč se z průmyslu dostal do plánovací komise, ředitel Vítkovic Rudolf Peška byl současně členem ústředního výboru.

Jistou roli sehrálo rovněž již zmíněné výlučné postavení někdejšího Severomoravského kraje. V tehdejší ekonomice hrál klíčovou roli, proto do něj také putovalo nejvíce investic a měl silné stranické organizace - především krajskou, ale i některé okresní. Respondent konstatuje, že kraj byl rozvíjen „monokulturně“; největší pozornost se věnovala průmyslu, zatímco v oblasti sociálních služeb byl rozvoj výrazně slabší. Je nicméně pravda, že pokud šlo o rekreace, dovolené apod., podniky byly nadstandardně vybaveny. Kraj byl výjimečný nejen výrobou, ale především jako zdroj surovin (např́íklad železa), které byly nezbytné pro rozvoj průmyslu v celé republice. K některým změnám nicméně docházelo: respondent například uvádí, že během osmdesátých let se stále více ukazovalo, že je velmi nízká zaměstnanost žen v kraji. $Z$ centra proto vzešly požadavky na budování pracovních míst pro ženy a následně od Zábřehu na Moravě po Rožnov pod Radhoštěm vznikaly Tesly, textilní závody apod. ${ }^{100} \mathrm{~V}$ nich pracovaly až z 90 procent ženy. Jednalo se o iniciativu z centra, podle respondentů č. 5 a 6 ale současně vycházela vstříc požadavkủm z míst: rodiny byly totiž dlouhodobě zatíženy třísměnnými provozy, které znamenaly extrémní podobu tradiční patriarchální dělby práce. (Muž byl téměř stále v práci, žena téměř stále sama v domácnosti.) Tato „výroba pracovních míst“ tak byla de facto součástí státní rodinné politiky.

100 Obě uvedená města leží za hranicemi dnešního Moravskoslezského kraje; vzdálena jsou od sebe zhruba $120 \mathrm{~km}$. 
Pokud jde o hodnocení plnění plánu, respondent uvádí, že ho měly na starosti stranické orgány. Každý měsíc se scházely závodní organizace, zkontrolovaly plnění, posunuly věc výše na podnikovou úroveň, a pokud bylo plnění v pořádku, podnik předal okresní organizaci podklady svědčící o tom, že je vše v pořádku, a tím proces více méně skončil. $V$ př́padě, že se objevil nějaký problém, přebírala iniciativu okresní organizace, která si začala zvát závody nebo podniky, které plán neplnily, a začala zjištovat důvody. $V$ př́padě, že byl problém $\mathrm{v}$ řediteli podniku a ten byl v okresní nomenklatuře, mohl okres prosadit prostřednictvím strany jeho výměnu. Strana měla tedy vliv především v personální rovině. Nomenklatura přitom sahala až $\mathrm{k}$ mistrům, kteří bývali v nomenklatuře výboru základní organizace strany, byt nemuseli být sami straníci. Základní organizace měly svou nomenklaturu opravdu pod kontrolou: respondent upozorňuje, že se nestávalo, že by základní organizace stála za svým člověkem a vyšší stranický orgán jej přesto vyměnil, i když se jednalo o nestraníka. Mezi technickými specialisty byla údajně jen malá menšina členů strany, mimo jiné „protože tenkrát se ř́ikalo, že komunistická strana je stranou dělnickou“. Členství ve straně bylo podle respondenta podstatnější v normalizačním období po roce 1970, kdy po čistkách v členstvu byli jasně preferováni straníci.

Naopak začátkem osmdesátých let došlo podle respondenta k uvolnění; přednost dostávali odborníci, kteří měli dobré jméno v kolektivu, měli respekt odborů, svazácké organizace a stranické organizace, straníky ale být nemuseli. Podle respondenta mohla být tvrdší kádrová politika v sedmdesátých letech do jisté míry setrvačná po předchozích čistkách - již usnesení z roku 1971 ke kádrové práci mělo být $\mathrm{v}$ této otázce mírnější.

Personální uvolňování mělo podle respondenta otevřít prostor pro začínající přestavbu - pro změnu centrální hospodářské politiky a pro další reformy chystané na patnáctý sjezd KSČ. V průběhu osmdesátých let se prvky přestavby projevovaly především v personálních otázkách: liberalizovaly se stranické organizace, přijímali se lidé vyškrtnutí po roce 1968. S doporučením od některého z „kovaných“ straníků se otevíraly možnosti vrátit se na pracoviště, do strany apod.

V otázce mzdových prostředků a fondů se v osmdesátých letech podle respondenta také mnohé měnilo; stát se vydával cestou otevírání možností motivovat pracovníky odstupňovanými mzdami. Motivační systém tak podle jeho hodnocení podněcoval k překračování plánu a k lámání rekordů; za nadstandardní výkony byly výrazné finanční bonusy pro pracovišsě i sociální služby, které organizovaly odbory. Je třeba vzít v úvahu také strukturu mezd: hospodářsko-techničtí pracovníci a administrativní personál míval hodinové mzdy, 
kdy motivační složku představovaly prémie. Pracovníci ve výrobě byli hodnoceni do jisté míry výkonově. Během osmdesátých let se objevovalo více experimentů s „chozrasčotem“, ${ }^{101} \mathrm{~s}$ řízením; mimo jiné se zaváděly možnosti př́mo obchodovat se Západem (nikoli pouze přes podniky zahraničního obchodu). „Socialistická soutěž “ podle respondenta poměrně dobře fungovala na úrovni odborů, které nekapitalisticky „soutěžily“ o rozsáhlé, společné fondy. Rekreacemi, lázněmi apod. se přitom posiloval kolektiv a pracovní morálka. Specifické motivační ocenění bylo udělováno za brigády socialistické práce, ocenění, které respondent označuje za „morální“, v podobě vyznamenání, určitých dílčích výhod, především však uznání.

Významnou složkou, jak potvrdil respondent, byly výrobně hospodářské jednotky, které přebíraly shora plán a musely se navzájem dokonale koordinovat, aby distribuovaly přidělené zdroje. VHJ, které do jisté míry - do svého zrušení v roce 1988 a následného převedení na státní podniky - fungovaly jako čtvrtý stupeň struktury řízení, sdružovaly podniky a mohly přizpůsobovat oceňování a rozdělování prémií podle výkonu podniků pod nimi sdružených (těch mohlo být i více než deset, přičemž některé z nich plán překročily, některé bojovaly $\mathrm{s}$ jeho plněním), mohly $\mathrm{v}$ určitých př́padech prevést část materiálu z podniku na jiný podnik apod. Oba respondenti č. 5 a 6 vnímají úlohu VHJ v osmdesátých letech jako prvek uvolnění přímého řízení z centra.

Obecně nicméně platilo, že nižší stupně neměly vliv na stupně vyšší, alespoň do úrovně VHJ (v hospodářské struktuře) a krajského národního výboru (ve stranické linii): celozávodní výbory neměly pravomoc vůči okresním výborům atp., lokální orgány měly lokální působnost.

V samotném ústředním výboru působili dle respondenta č. $6 \mathrm{v}$ souvislosti s naším tématem dva tajemníci: jeden pro národohospodářské otázky, který se věnoval vrcholovému plánovacímu systému, a druhý pro stranickou práci v průmyslu. Jistá podvojnost tedy byla prŕitomna již na vrcholu (stranické) hierarchie. Respondent působil v „národohospodářské“ funkci, která měla vazbu také na Prognostický ústav a na další přidružené instituce.

Respondent líčí, že na každém stupni aparátu (tj. na okresních výborech, krajských výborech a ústředním výboru) existovala skupina odborů a v rámci odborů oddělení, která se věnovala určitým odvětvím, například průmyslu,

${ }^{101}$ Chozrasčot (ruský výraz, zkrácená odvozenina pojmu chozjajstvennyj rasčot, čili hospodářský rozpočet) představoval pokus, zaváděný zejména v SSSR, spojit ve fungování podniků centrálně plánovanou ekonomiku s principem ziskovosti. Náklady a hospodářské výsledky měly být srovnávány v penězích; podniky měly více investovat $\mathrm{z}$ vlastních př́ijmů. Cílem bylo zvyšovat hospodárnost, výkon a návratnost. 
službám, zemědělství nebo školství. Oddělení měla své tajemníky, nad nimiž byl vedoucí tajemník. Jednotliví tajemníci dohlíželi na stranické organizace v př́slušných podnicích, které se na stranické úrovni rozčleňovaly do jednotlivých oblastí. Daný tajemník (například pro průmysl) tedy komunikoval s podnikem po dvou liniích: jednak s hospodářským vedením, jednak se stranickou organizací.

Podnikový plán, který vycházel z plánu Státní plánovací komise a který na podnik rozepsaly výrobní hospodářské jednotky, se dostal do rukou hospodářského vedení (celozávodního výboru) a základní organizace strany, jejímž členem byl ředitel závodu. Stranické organizace hlídaly výrobu a motivovaly $\mathrm{k}$ dodržování plánu. Zdroje informací, které měly $\mathrm{k}$ dispozici, vycházely vesměs z toho, co jim dodaly státní orgány a podniky; vlastní informační kanál neměly.

Mezinárodní spolupráce byla pochopitelně především na úrovni RVHP. Státní orgány určovaly, co se bude ze které země dovážet a do které země vyvážet - někdy vhodně, někdy na škodu. Výhoda byla nepochybně ve stabilitě, nebot v RVHP se zabezpečil odbyt na roky. Mezinárodní spolupráce na úrovni podniků existovala rovněž, ale byla slabší, „spíš taková společenská záležitost“.

Obecně byla dělba práce náročná, protože pro splnění plánu byla potřeba součinnost řady složek, subdodavatelů a podobně. Souhra podnikových, stranických a státních orgánů měla zajistit plnění plánu. Plán byl, jak uvádí více respondentů, spojen s určením mzdových prostředků, limitů na energii a na materiál. Při plnění plánu a dělbě práce tak měly vesměs navrch hospodářské složky, protože stranická složka vycházela z údajů, které se k ní dostávaly $\mathrm{z}$ hospodářské roviny. $\mathrm{V}$ zájmu větší součinnosti se svolávaly stranicko-ekonomické konference, kde se setkávalo hospodářské vedení, stranické organizace, zástupci odborů a svazáků. Ředitelé a náměstci (hospodářské vedení) v podstatě vytyčili plán v podnicích, zabezpečení výkonu, rozdělení úkolů apod. Stranické orgány měly plnění plánu a práci hospodářského vedení kontrolovat a vstupovaly do systému především ve chvíli, kdy se plnění plánu „Zadrhlo“. Odbory měly zajistit doplňkové služby včetně rekreací, de facto tedy motivační složku. Stranicko-hospodářské konference se konaly na úrovni podniků a VHJ, na úrovni ústředního výboru nikoli; tam fungovaly spíše komise, které zprostředkovávaly informace vedení po vlastní linii. Strana ale nevstupovala do procesu tak intenzivně i z toho důvodu, že byla závislá na informacích od hospodářského vedení. Nicméně vstupovala do hry především ve chvíli, kdy se neplnil plán nebo se objevily jiné problémy. V samotných podnicích měly v personálních otázkách silnou pozici odbory. Současně ale byli pracovníci hodnoceni podle 
ekonomických ukazatelů, tj. podle toho, nakolik ten který pracovník dosahoval požadované produktivity.

Podle respondenta byly přínosné pozdější „přestavbové“ experimenty, díky nimž se uvolňoval prostor pro aktivitu podniků, například snížením počtu sledovaných limitů (ukazatelů výroby a spotřeby), mj. v textilním průmyslu, a otevírala se cesta k prímému obchodu se Západem. Zvláštním příkladem bylo JZD Slušovice pod vedením Františka Čuby. Respondent uvádí tyto příklady jako ukázku, že socialistické hospodářství mohlo mít výrazně vyšší výkon, kdyby došlo k určitému uvolnění jak v plánování a kontrole, tak v obchodu. Úspěšné podniky v „experimentálních“ podmínkách o sobě mohly více rozhodovat, diverzifikovat výrobu a podobně. Širší zavedení podobných reforem nicméně vyžadovalo politické rozhodnutí na nejvyšší úrovni (na sjezdu strany). Respondent věrí, že podobné reformy se připravovaly, protože na koncepcích pracoval Prognostický ústav aj. Uplatňovala se „metoda hlavního článku“, kdy se určily priority kraje a zaváděly se programy pro jejich rozvoj - mimo jiné technologický. Jenže veškerý rozvoj brzdily limity (finančních zdrojů, materiálu nebo možností nabírat zaměstnance). Politické rozhodnutí by nicméně podle respondenta nestačilo: jako př́klad státu, který se rozhodl pro reformy a pro uvolnění hospodářství, uvádí Jugoslávii, která se nicméně př́iliš neprosadila. Nutné by byly reformy celého hospodářského systému, nedošlo však ani k prvnímu kroku; uskutečnily se pouze „pilotní“ experimenty, které měly pomoci ukázat, jakými cestami se měly reformy ubírat.

Respondent č. 7 (*1952, člen KSČ, Ing., perspektiva vedoucího výroby válcovny plechu)

Ve vztahu k centru uvádí respondent č. 7 podobné skutečnosti jako ostatní respondenti, vnímá nicméně určité posuny v čase. Podle něho se v osmdesátých letech především prohlubovaly mezipodnikové vztahy, podniky si navzájem dodávaly suroviny a do jejich součinnosti nutně nevstupoval centrální hospodářský orgán (hutnictví železa). Oproti dalším respondentům zdůrazňuje kontinuitu v tom smyslu, že řada podniků ani neměla jak ovlivňovat plán, protože ten byl nastaven na maximum kapacit. Podniky se snažily tyto kapacity pouze naplnit. Naplnění bylo tedy hlavní kritérium, zisk kritériem nebyl, přinejmenším ne v oficiální rovině: „o zisku se moc nehovořilo [...], tady se hovořilo o objemu výroby“. Respondent potvrzuje, že z hlediska požadovaného objemu docházelo ke změnám plánu spíše směrem k jeho dalšímu navyšování. Současně se stále více sledovala bezpečnost práce, kvalita výroby a poruchovost, které se přísně 
kontrolovaly a měly vliv na ohodnocení. S hodnocením kvality pak souvisela i jistá neprrímá konkurence mezi podniky.

$\mathrm{V}$ osmdesátých letech bylo podle respondenta zjevné zpomalení a především technologické zaostávání výroby. Respondent také uvádí značnou přezaměstnanost „na těch pomocných pracovištích, hlavně v té údržbě a v té administrativě “již na úrovni podniků.

Dále uvádí, že ještě v osmdesátých letech byla funkce mistra nebo vyšši (i technické) podmíněna členstvím ve straně: „o tom hodně rozhodovaly ty základní organizace strany, kdo půjde na mistra“. Konkrétně ve válcovnách plechu měly základní organizace sklon odmítat politicky nedostatečně důvěryhodné kádry, např́iklad „osmašedesátníky“, a jejich jmenování předáky nebo mistry blokovat. Potvrzuje tak, že v kádrových otázkách byl vliv strany značný, a to i na úrovni podniků a jejich závodů. Domnívá se, že to byl pro rozvoj hospodářství zásadní problém, dokonce, „že to byl hrob toho celého systému“. Strana si totiž mimo jiné hlídala nejlépe placené pozice, určití předáci měli opravdu vysoké platy, přezdívalo se jim „dělnická aristokracie“ a tyto posty si strana kontrolovala. Současně respondent upozorňuje, že výkon se pochopitelně sledoval také u členů strany na jakékoli pozici; pokud tedy stranický kádr pracoval špatně, prémie nebo odměny nedostával a sama strana se jej př́padně snažila nahradit schopnějším pracovníkem. Plnil-li se plán, personální zásahy shora nepřicházely; personální otázka se shora neřešila, dokud nebyly potíže s plněním. Což spadá do dosavadního profilu, kdy KSČ př́liš̌ nevstupovala do plánu (ani do toho podnikového), ale dohlížela na plnění, a „když se neplnilo, tak jako by přes tu partaj se tlačilo [...], ale přímo na plánu se nepodílela“.

Odbory přitom fungovaly v úzkém propojení se stranou. Na odborových schůzích se sice „někdy už objevovaly takové i zajímavější diskusní př́íspěvky, [...] ale nikdy to ani před rokem osmdesát devět nepřešlo do nějakého otevřeného rozporu s tím systémem“.

Za největší problém hospodářského systému a obecně režimu považuje respondent uzavřenost „, určité ulitě“, nedostatečnou pozornost věnovanou pokroku a rozvoji a špatnou personální práci jako „jednostranné hodnocení podle stranické knížky“. Ǩízení líčí jako prríliš centralistické (vedené shora dolů) a „těžkopádné“. 
Respondent č. $8\left({ }^{*} 1931\right.$, člen KSČ, absolvent Zemské vyšši rolnické školy $v$ Chrudimi, perspektiva préedsedy okresního národního výboru a následně ředitele národního podniku)

Respondent představoval podnikového ředitele, který se pokoušel jednat $\mathrm{v}$ rámci systému autonomně, přebírat zahraniční technologie a generovat zisk. Na rozdíl od ostatních respondentů nepracoval v klíčovém Severomoravském kraji, ale v tehdejším Východočeském kraji, nepůsobil v průmyslu a nebyl v prvé řadě vázán státním plánem. Spíše mu byly přidělovány podniky $\mathrm{k}$ - dnešním slovníkem řečeno - „revitalizaci“.

Oproti ostatním respondentům považuje zásahy, případně omezení ze strany okresního národního výboru (ONV) za časté a mnohdy destruktivní. Konkrétní tajemníky považoval mnohdy za neschopné a nezpůsobilé zasahovat do zemědělské výroby nebo čehokoli jiného. Tuto kritiku vztahuje i na období, kdy byl sám předsedou ONV ve východních Čechách, odkud přešel do upadajících Konzerváren a lihovarů Nové město nad Metují, které v následujících letech výrazně ekonomicky pozvedl.

Respondentova kritika nesměřuje na strukturu rozhodování $\mathrm{v}$ jejím celku, spíše na místní správní a stranické orgány. Správní orgány podle něho blokovaly rozvoj, stranické orgány pomáhaly krýt neschopné a destruktivní funkcionáře. Do obrazu řízení socialistických podniků přidává prvek nepotismu a klientelistických vazeb: funkcionář byl z jeho zkušenosti nejen neodvolatelný, ale bylo velmi těžké na něj působit, pokud se například dobře znal s vrcholnými představiteli strany (především s Jakešem nebo Indrou). Platí to i pro případ bývalého lihovaru ve Smiřicích, který respondent rovněž dostal do správy a kde „v bednách před mým nástupem bylo dodáno [...] technologické zařízení na výrobu pektinu za 76 milionů šilinků. Nikomu v zemi nevadilo, že tři roky leží v bednách." Podle rozhodnutí Štrougalovy vlády se přitom zahraniční technologie musely uvést do provozu do tří let. Za tím účelem bylo nicméně nutné vystavět fabriku, respondent ale nedostával územní rozhodnutí od místního ONV, kde stavbu blokoval vedoucí př́slušného odboru, člen Ústřední kontrolní a revizní komise a dobrý známý Miloše Jakeše, tehdy člena předsednictva ÚV KSČ. V takové konstelaci nebylo podle respondenta možné vymoci změnu rozhodnutí ani s podporou ministrů federální vlády ani najít závod, který by se stavby eventuálně ujal, a technologie zůstala po zbytek osmdesátých let nevyužita.

Další prríklad zásahu, tentokrát ze strany vlády, uvádí v souvislosti s ukončením výroby droždí v Libáni. Ta byla zastavena kvůli vypouštění odpadních vod do řeky. Podle respondenta šlo nicméně o iracionální zásah, kdy se znehodnotilo velké množství kvalitního droždí. Ani v tomto případě nepomohlo hledání 
zastání u vlády. „Bohužel se za věc nikdo nepostavil. [...] Takže náš stát začal dovážet náhradu z Jugoslávie za dolary.“

Například jednání na celostátní konferenci řídících a stranických kádrů v nomenklatuře krajských výborů KSČ líčí respondent jako málo efektivní, pohlcené „mobilizačni“ funkcí namísto racionálního ekonomického výhledu. Podobně „stranickou“ linii v podniku do značné míry opomíjel. Jako ředitel, který znásobil výrobu ve slabém koncernu, byl schopen generovat - především díky vývozu přes podnik Koospol - zisk, byt' v socialistickém hospodářství problematický, a dokázal si u př́slušných lidí leccos „,yhádat“, díky čemuž dosáhl na určité výjimky. Například po celou dobu v ředitelské funkci nejmenoval náměstka pro kádrovou a personální práci, jinak standardní součást podniků, „protože ředitel podniku, který neovládá rozhodující nástroj řízení, mzdovou politiku, neovládá kádrovou a personální funkci, nemá ve funkci zvláště ve velikém podniku co dělat".

Respondent především odmítá, že by pocítil nějaké „přestavbové“ posuny v řízení podniků; vesměs mohl dělat to, co si sám „vyhádal“ a co dokázal kompenzovat ziskovostí, plněním plánu, výsledky. Národohospodářské orgány včetně VHJ i stranické orgány označuje spíše za překážky rozvoje a za zcela zničující pak personální vazby a zneužitelnost správních i stranických funkcí, které značně brzdily rozvoj tehdejší ekonomiky.

Respondent č. 9 (*1961, člen KSČ, Ing. ekonom, perspektiva vědeckého pracovníka ekonomického výzkumného ústavu)

Respondent byl součástí výzkumného týmu, který řešil, jak zavést efektivní ekonomiku. Výstupy byly projednávány s vrcholnými stranickými orgány. Respondent uvádí, že „pro nás to stranické projednávání bylo hlavně o tom, aby nás to nechali dělat. Tam jsme to nebrali řekněme jako odbornou oponenturu, ale jako místo, které [...] to politicky rámuje [...]. Věcná oponentura probíhala na úrovni exekutivy a tedy na úrovni vědeckého výzkumu. Takže tam šlo o to vlastně obhájit smysl a existenci té práce. Samotná strana do těch závěrů v této fázi určitě nevstupovala, byt samozřejmě o to zájem měla. Nepochybně si šéfové toho výzkumu, tedy ředitelé těch ústavů, vyslechli své, ale myslím si, že to nepříliš [...] korigovalo to naše úsilí tam dole. Ta míra svobody zkoumání byla na tehdejší doby poměrně vysoká." Tomu odpovídalo i kádrové zabezpečení pracoviště, kde se objevovali i lidé, kteří neprošli stranickými prověrkami po roce 1968 a „dokonce lidé, kteří měli blízko disentu“.

Výzkumný tým pracoval na zadání jak zavést efektivní ekonomiku. Bylo jasné, že navržené řešení bude muset zahrnovat jak hodnotový mechanismus a trh, 
tak prvky plánování. Výzkum tedy směřoval k „plánovitě usměrňovanému trhu“, který by generoval základní ekonomické informace a umožňoval demokratické, participativní plánování, jež by nezáviselo na „byrokratickém molochu vytrženém z ekonomické reálie“.

V praxi se ovšem za celé období nepodařilo byrokratické plánování překonat. Hlavním důvodem byla „obrovská setrvačnost“"v rozhodovací sféře, u politického zadavatele, tedy ve vedení strany. To se jasně projevilo např. při př́ípravě hospodářské reformy, kterou měl schválit XVIII. sjezd strany v roce 1990. Šlo mj. o otázky, do jaké míry připustit soukromé podnikání. „A tam teda byla obrovská setrvačnost, viz debaty okolo zákona o státním podniku [...]. Když omezíme vliv plánu, do jaké míry bude vpuštěn do hry tzv. kapitalismus? Protože ta hra [...] tržních sil automaticky některým lidem v logice určitých přístupů splývala s kapitalismem. Takže tady ta setrvačnost byla obrovská, a kdyby nedošlo $\mathrm{k}$ roku 89 , tak ta bitva o hospodářskou reformu by byla velká [...]. Jestli my jsme zkoušeli některé reformy z padesátých a šedesátých let jako jedni z nejodvážnějších, tak tady když to přišlo v osmdesátých letech, [...] jsme byli naopak ti nejopatrnější. Opatrnější než my byli už jen v NDR." Sovětští ekonomové byli v průběhu perestrojky výrazně v předstihu, nicméně jejich modely zůstávaly převážně akademické a prakticky málo uskutečnitelné.

Pokračovala extenzivní ekonomika a nedošlo k naplnění Leninem definované mety, tedy aby socialismus porazil kapitalismus tím, že jej předstihne v produktivitě práce. Vytvářely se „polotovary a poloreformy [...]. Vykročilo se $\mathrm{k}$ něčemu, a než se to rozběhlo, tak se to zhroutilo. Tak jsme se vrátili k ,ověřenému' $[\ldots . .$. ."

Navíc trval „technologický gap“ - zaostávání za vyspělejšími zeměmi o patnáct až dvacet let, tedy prakticky o jeden celý inovační cyklus. Systém dále neumožňoval dodržování obecně uznávaného principu odměňování podle práce. Respondent uvádí, že se politekonomové zabývali tím, jak simulovat trh práce a zda by pracovní síla nemohla být chápána jako „nositel společensky uznané práce“, který by procházel „nějakým tržním praktickým ověřením“ a o jehož odměně by se pak nerozhodovalo administrativně - ovšem tento výzkum „pravděpodobně ani nedorazil na ÚV“. Nejdále se dostaly úvahy o „uvolnění řízení státních podniků, které neměly mít tu pevnou pupečníkovou šňůru na rozpočtové dotace“; měly mít možnost generovat zisk a do jejich řízení již neměla prímo zasahovat strana.

Respondent se podrobně vyjadřoval k procesu plánování a potvrdil tezi Lubomíra Mlčocha o „hře o plán“. V praxi se dle respondenta o plánu rozhodovalo v centrálních institucích, „ale když byl návrh plánu a když se v té VHJ 
dozvěděli, a to se zase dozvěděli at už formálně, ale i neformálně, [...] co se chystá, tak pan generální ředitel toho př́slušného koncernu [...] vyrazil směrem bud' kraj, nebo Praha a začal jednat. A ted' použil těch svých možností a metod formálních i neformálních a řekl: ,Neblázněte, když uděláte takovýto plán, my ho stejně nesplníme a budete mít průšvih.“ A Aktéŕi tak do „centralizovaného dirigistického systému“ vnášeli „finty a stupně volnosti, které umožňovaly se v něm pohybovat. Ale opět to byly v podstatě techniky, které nesouvisely s ekonomikou, ale s vyjednávací silou. [...] Ty umožňovaly, že ten systém jel možná ne dobře, ale jel.“ Neexistovala ani klasická konkurence v tržním slova smyslu, ale „konkurence v těch neformálních vztazích. Při vyjednávání o plánu, při získávání zakázek, v dodavatelsko-odběratelských vztazích [...]“. Strana pak představovala „jedno z těch vyjednávacích polí, protože byly decizní orgány, byly stranické orgány, byly nějaké mezipodnikové vztahy [...]. Takže na těchto třech základních polích - tam se to odehrávalo.“

Situace si tak vynutila manažery podniků, kteří měli velmi specifické dovednosti: „nebyli [to] nějací jenom byrokrati, kteří by měli klotové rukávy a drželi by se papíru. Ne. Ti se právě v tomto zvláštním hybridním prostředí museli umět pohybovat, jinak by nesplnili plán, nebyly by prémie, nebyli by ředitelé, protože tam byla moc státu je odvolat“. V důsledku se „[...] všichni [...] nějak podílejí na tom rozhodování, [...] jestli má být cílem naplnit nebo obelstít ty administrativní směrnice anebo zda tím cílem má být ekonomická kvalita. Primárně samozřejmě obelstít, protože ta ekonomická kvalita byla dána nějakým administrativním úkolem“.

\section{Závěr}

Působení strany při řízení centrálně plánované ekonomiky výrazně rozdělovalo dobovou společnost a dokonce i samu stranu. Na jedné straně orgány a funkcionáři KSČ tuto roli vnímali zcela nebo alespoň za splnění konkrétních podmínek jako konstruktivní. Na druhé straně vedoucí hospodářští pracovníci roli strany vnímali bud' jako zvláštní součást státního aparátu, s níž bylo nutné nějakým způsobem spolupracovat a „vycházet“, nebo jako dodatečnou byrokratickou zátěž a politizaci ekonomiky, která deformovala hospodářské prostředí, v horším př́ipadě jako voluntaristický subjektivní zásah do fungování podniků a vážnou překážku jejich rozvoje.

To se projevovalo zejména ve vztahu k potřebám měnit způsob fungování centrálně plánované ekonomiky. Pro rozhodující část vedení KSČ a stranických funkcionářů představovalo zjevně Poučení z krizového vývoje normativní 
dokument trvalého významu. Tato část strany proto odmítala až do roku 1989 jakékoli systémové změny a reformy, zvýšení výkonnosti ekonomiky se hledalo maximálně v úpravách hospodářského mechanismu a jeho „vylepšování“, akcent byl kladen na zlepšení stranicko-organizační, ideologické, kádrové a kontrolní práce strany.

V přístupu k řízení ekonomiky tak byla stále patrnější vnitřní diferenciace stranického vedení - aktéri, kteří se zabývali především hospodářstvím a měli v něm svou expertízu, měli sklon $\mathrm{k}$ odbornému hospodářskému pohledu a ke snaze o úpravu nebo změnu systému (Štrougal, ekonomická oddělení ÚV KSČ, od roku 1987 i Husák), perspektivně s tendencí k decentralizaci a depolitizaci hospodářství. Aktérii, kteří kladli důraz na stabilitu režimu a ideovou čistotu strany a de facto se přidržovali normativního charakteru Poučení z krizového vývoje (křídlo Jakeše, Fojtíka, Indry), naopak hospodářské otázky politizovali, ideologizovali a soustředili se na lidský faktor, výchovu a disciplínu.

Jak uvádí např. Jiří Dolejš, „strana se neuměla v osmdesátých letech reformovat a integrovat své bývalé členy vyloučené po roce 1968. Mnohé by se asi vyvíjelo jinak, kdyby působili někteří z těchto lidí v reformované komunistické straně. Tak dlouho se ale práskalo nad hlavami nezávislých myslitelů bičem revizionismu, až se podařilo jakékoli širší levicové řešení udusit v zárodku. " 102

$\mathrm{K}$ jednoznačnému závěru o možnostech změny dospěl Lubomír Mlčoch: uzavřený hierarchický plánovací systém nelze efektivně „zdokonalovat“, ba dokonce reformovat: prostě je třeba jej v principu opustit. ${ }^{103}$ Antonín Kotulan uvádí, že „utopením vědy v dogmatu se učení Marxe a Engelse dostalo do sféry, kterou praxe a zkušenost nemohly zasáhnout. Motivem byla obava, resp. předkládané „zdůvodnění“, aby zkušenost nevnesla jasno do věci a aby pak nezacloumala některými vůdčími myšlenkami a „neoslabila ideologický boj“. Vědecký přístup nahradil bezzásadový empirismus a „revize“ v podobě hledání hesel k ospravedlnění změn, odchylek od dogmatu. Pouze nejvyšší politické autority se mohly vyslovovat o zásadních věcech doktríny a dokonce i ony byly obezřetné, aby vyjádřily nové myšlenky „tvůrčím způsobem“ ve starých formách „v duchu rozvíjení dědictví“. 104 Skutečnost byla vyvozována $\mathrm{z}$ „apriorně fixovaných idejí“. 105

\footnotetext{
102 Jiří Dolejš, Levice mezi minulostí a budoucností (Praha: Svoboda Servis, 2010), 8.

103 Mlčoch, Chování československé podnikové sféry, 210.

104 Antonín Kotulan, „Zásady institucionálního uspořádání socialistické společnosti a jejich zdůvodnění v díle K. Marxe a B. Engelse“, in Přestavba hospodářského mechanismu, ekonomické klima a institucionální uspořádání ekonomiky, ed. Antonín Kotulan et al. (Praha: Ekonomický ústav ČSAV, 1990), 49-50.

105 Ibid., 50.
} 
Veškeré změny se tak za působení vedoucí úlohy strany stávaly předmětem posuzování z hlediska postavení strany, stability politického systému a ideologického dogmatu. Např. zavádění komplexního experimentu (ve vybraných VHJ a podnicích od roku 1988), který zvyšoval samostatnost a zainteresovanost na zisku vybraných VHJ a podniků, bylo bedlivě sledováno a v prvních náznacích zjevně vedlo k posílení manažerské a finanční samostatnosti a k tendenci oslabit vliv strany.

Stranické orgány při řídící činnosti sledovaly jak odbornou ekonomickou linii (opíraly se o práci hospodářských pracovníků, jen omezeně měly vlastní informační zdroje a analýzy), tak linii práce strany. Vedle určování dlouhodobých strategických směrů politiky (sjezdy a jejich rozpracování na plenárních zasedáních ÚV KSČ) se zabývaly primárně ideovými, organizačními a kádrovými otázkami budování strany jako nástroje vedení a kontroly. Doporučení měla velmi často obecný apelační a mobilizační charakter, a to v obou oblastech, přičemž se málo týkala systémových prvků, ale spíše se zabývala ideovým působením na stranu a pracující.

Velký důraz na organizovanost (tedy přijetí zaměstnanců do KSČ) naznačuje, že ve straně převládalo přesvědčení, že nejjednodušší a nejlevnější (protože mimoekonomickou) formou řízení je obsazení všech důležitých pozic straníky nebo přijetí všech odpovědných hospodářských, administrativních a technických pracovníků do strany. Takovým členům strany pak bylo možné přímo zadávat úkoly, kontrolovat jejich činnost i vyžadovat loajalitu, odpovídající výkony a poslušnost.

Vztah k společenským organizacím byl čistě instrumentální (převodové páky stranické politiky) a strana jim věnovala poměrně malou pozornost. Tam, kde se jimi zabývala, vyjadřovala málo reálná, a tedy de facto formální očekávání (viz např. požadavek, aby Reflektor mladých odhaloval nedostatky v činnosti ministerstva průmyslu).

S jistým zjednodušením je možné hovořit o tom, že strany realizovala ve skutečnosti svoji „,vedoucí úlohu“ prostřednictvím několika funkcí.

Funkce př́má řídicí - KSČ určovala strategické směry vývoje hospodářství, kádrové obsazení všech klíčových hospodářských, často i technických postů v národním hospodářství, disciplinovala, kontrolovala a sankcionovala (ne)naplňování svých normativních aktů. Jednalo se z hlediska centrálně plánované ekonomiky o funkci systémovou.

Funkce zprostředkujicí - strana přenášela centrálně přijímaná rozhodnutí směrem dolů (top-down), organizovala jejich plnění, v opačném směru (bottom-up) ale mohla informovat o stavu na místě a lobbovat za zájmy místních 
ekonomických subjektů (úpravy plánů atd.). Při kreativní práci s plány, která byla pro řadu oblastí ekonomiky typická („hra o plán“), mohla mít tato funkce reálný hospodářský význam a byla v podstatě nesystémová.

Funkce koordinační - na své úrovni stranické orgány propojovaly horizontálně hospodářské, správní a politické subjekty a usilovaly o dělbu práce při plnění plánů a stranických normativů. V podmínkách nedostatkové ekonomiky a napjatých subdodavatelských vztahů mohly stranické orgány sehrát nápomocnou roli, ovšem opět vně samotného systému centrálně plánovaného hospodářství.

Funkce apelační a mobilizační - svou ideovou aktivitou, ideologickou výchovou a dobovými rituály (oslavy výročí, vyzdvihování výkonů pracovníků a kolektivů atd.) se strana snažila získávat své členy a ostatní aktéry pro vyšší výkony, posilovat jejich disciplínu, ,ideovou jednotu“ a bojovat proti politické i intelektuální herezi, která by zpochybnila fungování hospodářského a poté i politického systému. Ostatně strana byla někdy popisována jako nejideologičtěji orientovaná strana celého východního bloku. ${ }^{106}$

Hodnocení, jak strana tyto funkce, které si sama připsala, naplňovala, záleží na úhlu pohledu. V této práci jsme použili zápisy nejvyšších stranických orgánů, rozhovory se stranickými funkcionáři regionální úrovně a vedoucími hospodářskými pracovníky ve výrobě.

$\mathrm{V}$ pohledu na systémové působeni strany se představitelé strany a vedoucí hospodářští pracovníci rozcházejí: vedení strany a funkcionáři podvojnost systému (strana a státní orgány) nezpochybňují: vidí to (alespoň potenciálně) jako výhodu. Hospodářští pracovníci naopak vnímají zásahy strany často jako cizí prvek, který fungování ekonomiky zatěžoval.

Jak orgány strany a její funkcionáři, tak hospodářští pracovníci shodně vnímají působení strany jako nevyrovnané, spojené výrazně s nesystémovým, subjektivním faktorem. Jeho hodnocení má ovšem odlišnou podobu: Výše uvedený rozbor dokumentů z jednání nejvyšších orgánů KSČ ukazuje, že pojmem subjektivní faktor označovaly důvody selhání stranických a hospodářských orgánů a aktérů při naplňování hospodářských plánů a role strany; nikoli hospodářský systém, ale aktéři a konkrétní orgány byli zodpovědní za neúspěch.

Naopak vedoucí hospodářští pracovníci uvádějí příklady subjektivního postupu jako projevy voluntarismu, kdy řízení ekonomiky do značné míry záviselo na kompetentnosti, na osobních, de facto patrimoniálních vazbách

106 Judy Batt, Economic Reform and Political Change in Eastern Europe: a Comparison of the Czechoslovakian and Hungarian Experience (London: Macmillan, 1988), cit. dle Gerry N. Marks, „Communist party membership in five former Soviet bloc countries, 1945-1989“, Communist and Post-Communist Studies 37, č. 2 (červen 2004): 242, doi: 10.1016/j.postcomstud.2004.03.004. 
a na osobním charakteru konkrétních představitelů strany. V zásadě tak platilo, že tam, kde stranickou funkci zastával kvalitní pracovník, mohl naplňovat funkce strany tak, že minimalizoval dodatečnou byrokratickou zátěž, již fungování podvojného řízení objektivně představovalo. $V$ „kontrolní skupině“ či „ř́idící koalici“ pak mohl takový funkcionář strany sehrávat důležitou roli při zajištění fungování podniku (viz „hru o plán“, jak ji uvádí Mlčoch). Obsazení stranických funkcí nekvalitními kádry naopak představovalo pro fungování podniků dodatečnou překážku (vedle funkčních chyb hospodářského systému). Zvláštní kategorii nesystémovosti a voluntarismu představoval aktivismus, který mohl napomáhat dobrým hospodářským výsledkům, působil ale proti samotnému principu centrálně plánované ekonomiky (např. Miroslav Mamula a nařízení, že Severomoravský kraj ve čtvrtém čtvrtletí plnil plány již podle normativů příštího roku). 